GEOLOGY OF RUBY RIDGE, SOUTHWESTERN BROOKS RANGE, ALASKA

By W.G. Gilbert, M.A. Wiltse, J.R. Carden, R.B. Forbes, and S.W. Hackett

GEOLOGIC REPORT 58

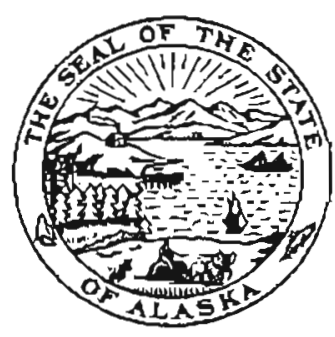


STATE OF ALASKA

Jay S. Hammond, Governor

Robert E. LeResche, Commissioner, Dept. of Natural Resources

Ross G. Schaff, State Geologist

Cover photo: Helecitic garnet in glaucophane-bearing metabasalt from Ruby Ridge (X46).

For sale by Alaska Division of Geological and Geophysical Surveys, P.O. Box 80007, College, 99708; 3327 Fatrbanks St.. Anchorage, 99503: P.O. Box 2498, Ketchikan, 99901; and Pouch M, Juneau, 99811. 


\section{CONTENTS}

Page

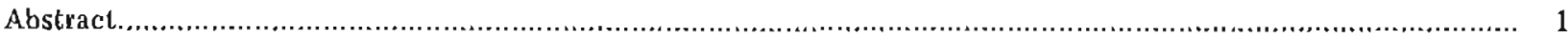

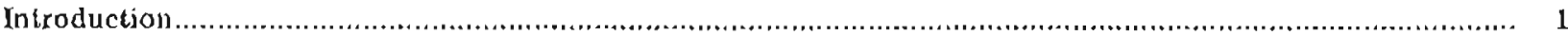

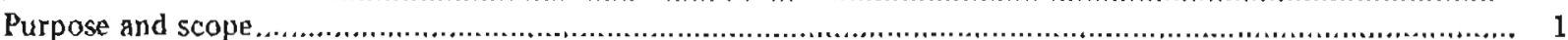

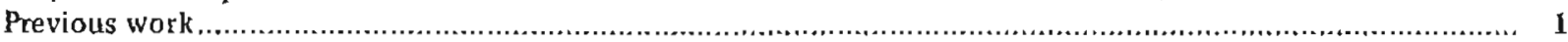

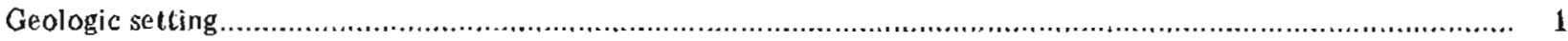

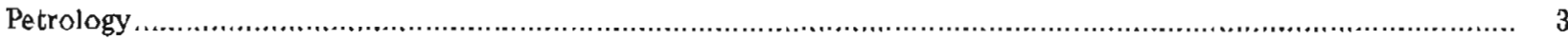

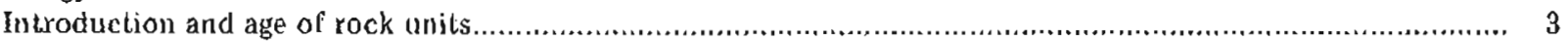

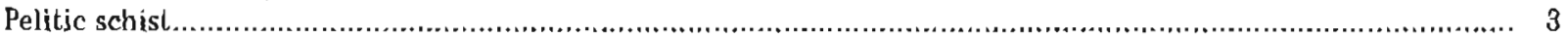

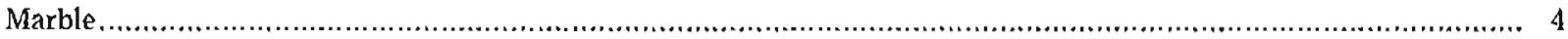

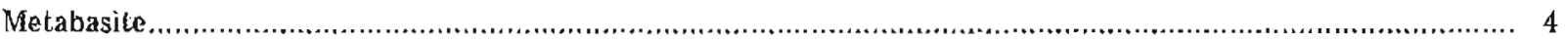

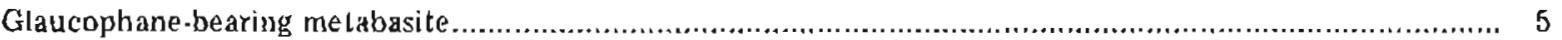

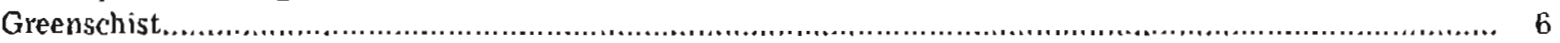

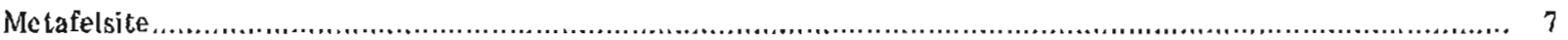

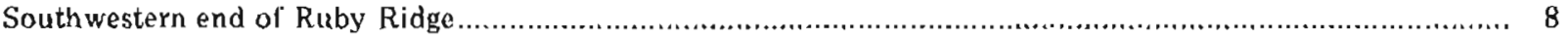

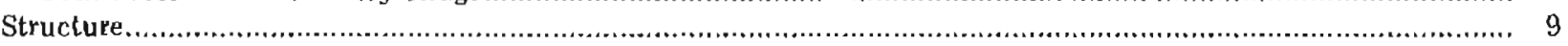

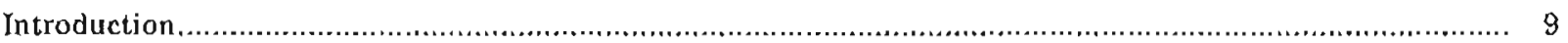

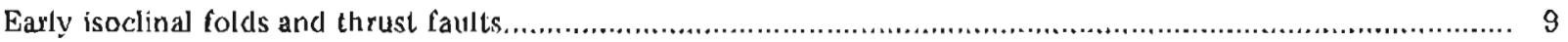

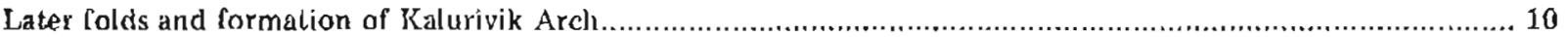

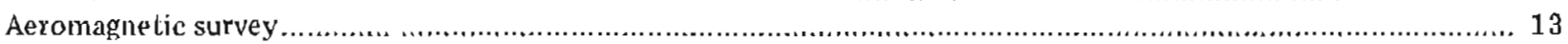

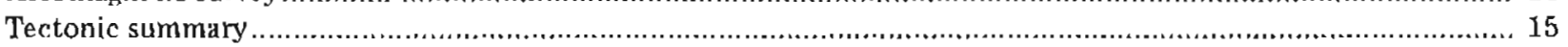

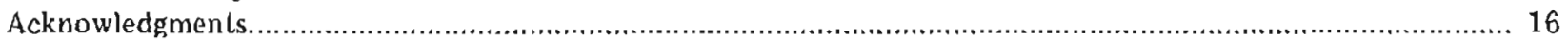

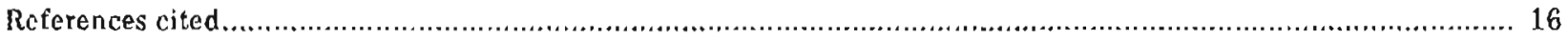

ILLUSTRATIONS

PLATE 1. Geology of Ruby Ridge, soulhwestern Brooks Range, Alaska .................................................. In pocket

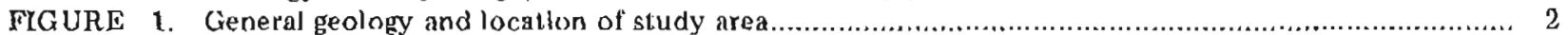

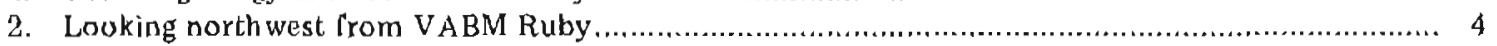

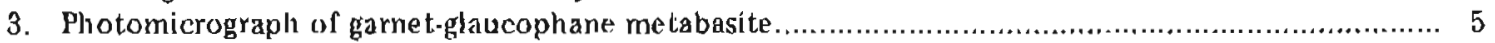

4. Pholomicrograph of retrograded glaucophane-bearing metabasite ..................................... 6

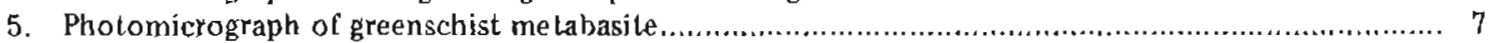

6. Photomicrograph of greenschist metabasite showing chlorite forming from garnet...................... 8

7. Photograply of south-dipping marble $0.6 \mathrm{~km}$ west of peak 2100 on southwestern end of Ruby Ridge.

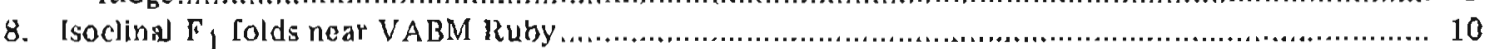

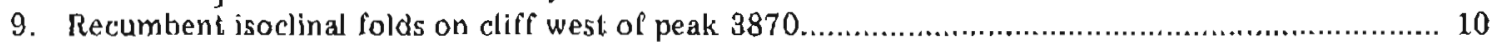

10. Lower hemisphere equal-area plot of $17 \mathbb{F}_{1}$ fold axes................................................. 11

11a. Lowey hemisphere equal-area plol of 167 poles to $\mathrm{S}_{1}$ foliation north of Kalurivik Arch along

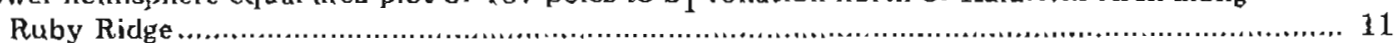

11b. Lower hemisphere equal-area plot of 127 poles to $S_{1}$ foliation south of Kalurivik Axch along Ruby Ridee

\section{1}

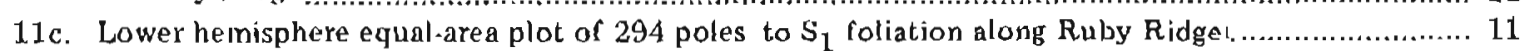

12. Trace of thrust fault on ridge northeast of VABM Ruby ................................................ 12

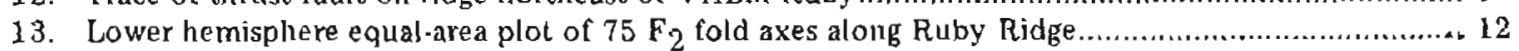

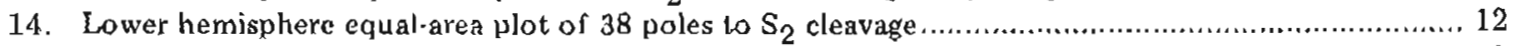

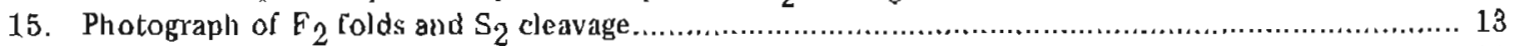

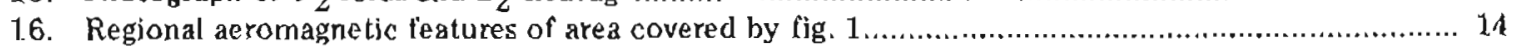

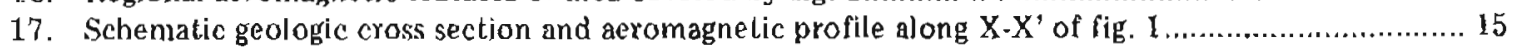

\section{TABLE}




\title{
GEOLOGY OF RUBY RIDGE, SOUTHWESTERN BROOKS RANGE, ALASKA
}

\author{
By W.G. Gilbert, ${ }^{1}$ M.A. Wiltse, ${ }^{2}$ J.R. Carden, ${ }^{3}$ R.B. Forbes, ${ }^{3}$ and S.W. Hackett ${ }^{1}$
}

\begin{abstract}
Ruby Ridge contains a polymetamorphic assemblage of pelitic schist and lesser amounts of metabasite. metafelsite, and marble. Pelitic schist is generally muscovite-quartz schist but includes chloritoid-bearing, graphitic, and calcareous units. Metabasite lenses within the pelitic schist vary between glaucophane-bearing and greenschist varieties. Most of the pelitic schist, marble, and metabasite was metamorphosed in the blueschist facies in late Precambrian time. The metafelsite generally conlains biotile and microcline and is either of mid-Paleozoic or Cretaceous age. Weakly metamorphosed rocks on the tip of the ridge are probably either continuous with Paleozoic rocks in the Cosmos Hilts or are the low-grade part of a progressively metamorphosed terrane.

Greenschist-facies metamorphic segregation, thrust faults, and isoclinal to subisoclinal folds overturned to the north developed during widespread Cretaceous teclonism and plutonism. Open to subisoclinal folds, slip cleavage, and, perhaps, the Kalurivik Arch formed during Late Cretaceous or Tertiary time.

Linear zones of high magnetic intensity lie over the Cosmos Hills and uplands of the Baird and Schwalka Mountains. Broad magnetic lows and highs occur over the southern portion of the schist belt, and flat magnetic lows occur over the Ambler Lowland. The aeromagnetic evidence suggests that the teclonic boundary between the Cosmos Hills-Angayucham cerrane and the schist belt was reactivated as a strike-slip system during Tertiary time.
\end{abstract}

\section{INTRODUCTION}

\section{PURPOSE AND SCOPE}

This study is the result of cooperative efforts between the Alaska Division of Geological and Geophysical Surveys (DGGS), the U.S. Geological Survey, and the University of Alaska to oblain detailed information on the structure, petrology, and mineral deposits of the southern Brooks Range schist belt. In 1973, Forbes, Gilbert, and Carden began a reconnaissance study of the ridge containing VABM Ruby-here-

\footnotetext{
${ }^{1}$ Alagka Dlvision of Geological and Geophysical Surveys, Col-

lege, AK 00708 .
Pacific Cordiliera Exploration, SRA 20826, Fnirbanks, AK 99701 .

3 Solld-Earth Scionces Program, College of Environmental Sciences, Universily of Alaska, Falrbanks, AK 99701.
}

inator referred to as "Ruby Ridge"-and Gilbert and Wiltse completed the geologic traverse in 1975. Field work was accomplished by foot traverses from helicopter-supported base camps. The geology along Ruby Ridge, petrography of approximately 100 thin sections, and results of an aeromagnetic survey of the west-central Brooks Range by Hackett are summarized in this report.

\section{PREVIOUS WORK}

Fritts $(1969,1970)$ reported on the geology and mineralization of the Cosmos Hills, located south of Ruby Ridge, and of the Angayucham Mountains in the northwestern Hughes quadranglo (Fritts, 1971). Results of the Alaska DGGS field studles in the southwestern Survey Pass quadrangle were reported by Fritts and others (1972). Forbes and others (1974) presented preliminary results of the traverse along Ruby Ridge and listed metamorphic mineral assemblages encountered. Pessel and others (1973a,b), Pessel and Brosge (1977), and Brosge and Pessel (1977) have summarized the regional geology of the southern Brooks Range. Turner (1974) and Turner and Forbes (1977) reported on geochronology of metamorphic rocks collected from the schist belt.

\section{GEOLOGIC SETTING}

Ruby Ridge, located in the northern part of the Ambler River A-2 quadrangle and southern part of the Ambler River B-2 quadrangle, extends from the end of the ridge $9.0 \mathrm{~km}$ north of the settlement of Bornite portheast for aboul $26 \mathrm{~km}$ (1ig. 1). The ridge is within the western Brooks Range schist belt as defined by Fritts and others (1972), Pessel and others (1973b), Pessel and Brosge (1977), and Brosge and Pessel (1977) (fig. 1). The schist belt contains pelitic, gsammitic, and calcareous medisediments and metaigneous rocks, metamorphosed to prehnite-pumpellyite, blueschist, and greenschist facies. Mica-quartz schist and metabasite are the most conspicuous rocks in the belt. The schist bell is largely separated from extensive limestone, calcareous schist, and Cretaceous intrusive terranes to the north by the Walker Lake lineament (Fitts and others, 1972; Pessel and others, 1973a,b). The southern margin of the schist belt generally forms the north side of the Ambler Lowland (fig. 1).

The metamorphic history of the schist belt is com- 


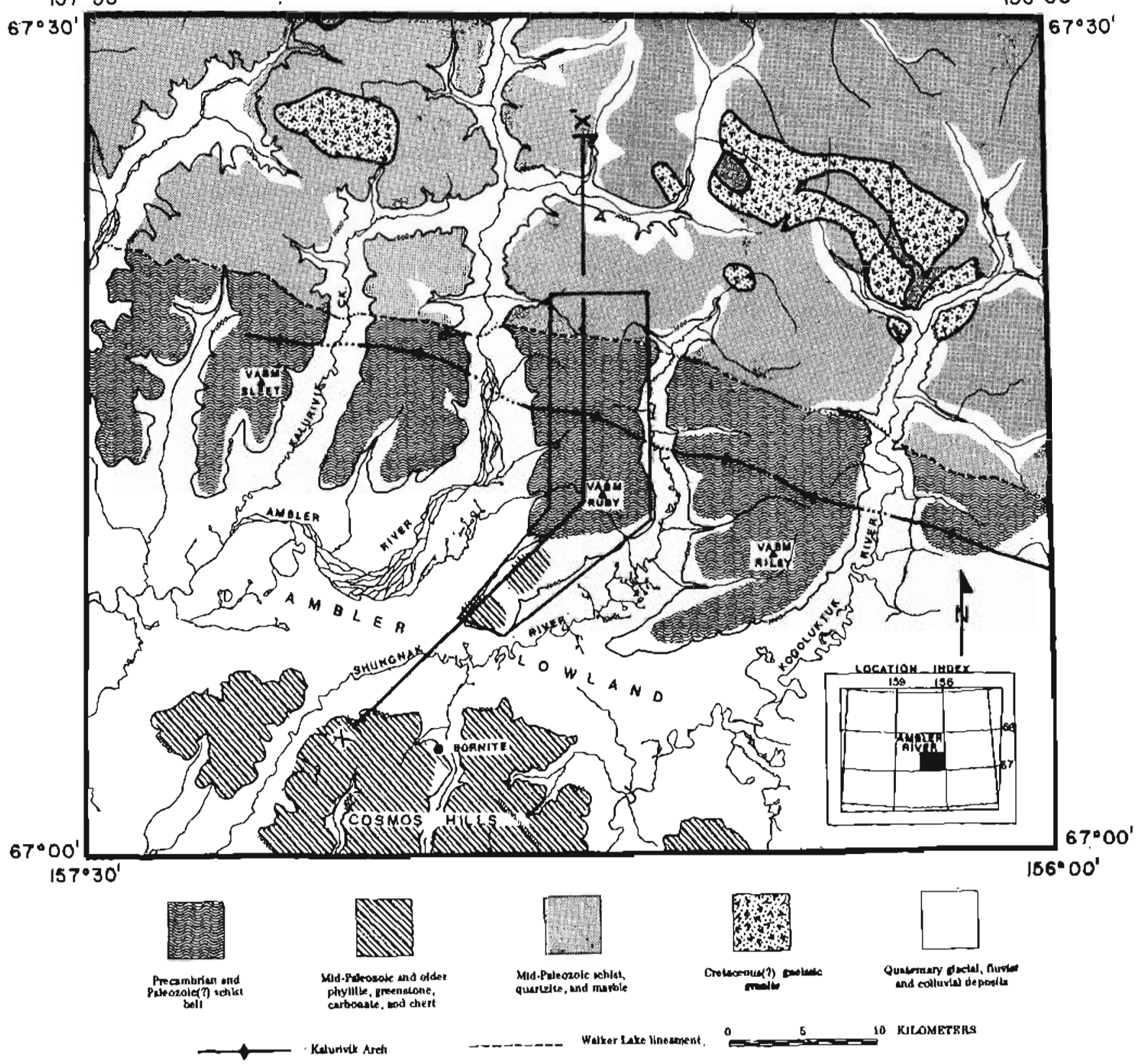

Figure 1. General geology and location of study area. X'X' shown in fig. 17.

plex and not completely documented. Potassium-argon $\left(40 \mathrm{~K} /{ }^{40} \mathrm{Ar}\right)$ ages derived from the schist-belt on metabasite and quartz-mica schist suggest that some schiscbelt rocks may be Precambrian (Tumer, 1974; Tumer and Forbes, 1977). A Cretaceous regional thermal event ussociated with emplacement of granitic plutons is also suggested by radiometric ages (Palton and others, 1968; Tumer, 1974; Mayfield, 1975; Turner and Forbes, 1977). The thermal pulse associated with the intrusion of Cretaceous plutons may have locally reset $40_{\mathrm{K}} / 40_{\mathrm{Ar}}$ ages for considerable distances around the larger in- trusions.

Some rocks in the schist belt, however, may be equiv. alent in age to metamorphic units of the Angayucham Mountains-Cosmos Hilis to the south (Wiltse and Gilbert, 1977) (ng. 1). Devonian(?) fossils are reported by Brosge and Pessel (1977) from a marble interval in the schist belt $42 \mathrm{~km}$ east of Ruby Ridge. Marbles yielding Devonian fossils have atso been reported from metabasite-bearing sequences in the Cosmos Hills (Fritts, 1970) and the Angayucham Mountains (Patton and others, 1968; Fritts and others, 1972). The Angayucham 
basalt may be in part Perminu in ago as suggested by Possils reported by Pation and Miller (1973) from correlative units in the central Brooks Range. Proponents of a Permian age for the Angayuchain Mountains (and by extension, the melabasite of the Brooks Range schist belt) suggest that the Devonian(?) or older carbonate of both areas was emplaced lectonically by thrust faulting or by infolding (Tajlleur, pers. comm.).

The most pronounced structure along the schist belt is a large antiform, the Kalurivik Arch (Pessel and others, 1973a). Several west-trending antiformal upwarps, including the Kalurivik Arch, which persist from the Redstone and Shishakshinovick plutons on the north to the core of the eastern Cosmos Hills on the south (Pessel and others, 1973b; Fritts, 1971), may have formed by uparching during emplacement of Cretaceous plutons.

East of the map area the Walker Lake lincament is thought to be a regional thrust lault separating the schist belt on the south from a carbonate-rich terrane to the north (Fritts and others, 1972; Pessel and others, 1972a,b). The fault may die oul to the west as an un. conformity (Pessel, pers. cornm.).

The Ambler Lowland is thought to be the locus of a thrust fault (Fritts and others, 1972) or of a synclinal trough (Pessel and others, 1973b).

\section{PETROLOGY}

\section{INTRODUCTION AND AGE OF ROCK UNITS}

The rocks exposed on Ruby Ridge are domindiely a polymetamorphic assemblage of quartz-rich pelitic schist and lesser amounts of marbie, melabasite, and melafelsite. The different rock types commonly occur together, but the marble and metabasite axe most abundant near VABM Ruby and near peak 3870 on the north end of the ridge, and the metafelsite is exposed only near VABM Ruby (pl. 1).

Metapelite and metabasite exhibit effects of at least two periods of regional dynothermal metamorphism. The first metamorphic event recrystallized the rocks in the blueschist facies and a second thermal event, more intense to the north, partially or completely recrystallized these rocks in the greenschist iacies. The metafelsite appears to have been affected by only the second event.

Radiometric evidence (Tumer, 1974; Tumer and Forbes, 1977) indicates that most of the intercalated pelitic schist, marble, and metabasite on Ruby Ridge represents Precambrian basement. However, workers who have studied the metafelsite do not agree on its origin and age. Authors Wiltse and Gilbert bclieve the metafelsite represents felsic volcanic rocks of probable mid-Paleozoic age that unconformably overlie Precambrian basement and are now tectonically intercalated with it, whereas authors Forbes and Carden suggest that the metrfelsite on Ruby Ridge represents hypabyssal apopbyses of Cretaceous granitic intrusions that were emplaced synkinematically during the second major metamorphic event.

Weakly metamorphosed phyllite, metabasalt, and marble crop out on the low, southwesternmost part of Ruby Ridge (pl. 1). These rocks are probably either continuous with Paleozoic(?) rocks in the Cosmos Hilis to the south rather than with the main part of the schist bejt to the north (Gilbert, Wiltse, and Carden), or are the low-grade part of a progressively metamorphosed terrane that increases in grade to the north (Forbes).

\section{PELITIC SCHIST}

Brown-weathering muscovite-quartz schist volumetrically dominates the rocks exposed on Ruby Ridge. The schist is fine to medium grained and rarely contains large porphyroblasts of albite or garnet. Schistosity is defined by the parallel alignment of chlorite and white nica, and a second S surface defined by slip cleavage parallel to axial surfaces of small crenulations is oc casionally present.

Quarc and muscovite ate the dominanl minerals in the pelitic schisl, although chloritoid, graphite, chlorite, calcite, garnet, and albite occur locally. Trace amounts of sphene and apatite are nearly ubiquitous.

Chloritoid-bearing mica schist occurs in jrregular east-west-irending horizons severat meters thick near VABM Ruby. These rocks contain quartz, muscovite, chloritoid, graphite, glaucophane, and chlorite, trace amounts of albite, and small (1-mm-dia) garnet porphyroblasts. Similar schist is found on a ridge $8-10 \mathrm{~km}$ southeast of VABM Ruby and near the north end of Ruby Ridge, where a chlorite-bearing chloritoid-biotitemuscovite quart7, schist is present. Chloritoid-bearing mica schist exhibils well-segregated, crenulated layers of muscovite and chloritoid separated by bands of finegrained quartz; except for the presence of chloritoid and glaucophane, the schist is similar to "normal" mica-quartz pelitic schist. Chloritoid probably crystallized at the same time as muscovite. Small patches of pennine chlorite are scattered throughout the inuscovite. chloritoid layers. Chlorite rarely truncates or transecls muscovite, but more commonly precedes muscovite in the paragenetic sequence. Albite is rate in chloritoidbearing rocks, and small (1.5- $\mathrm{mm}$ dia), colorless to orange, skeletal to euliedral garnet is rare. The garnet formed late in the paragenetic sequence.

Lenses of black graphitic schist up to several meters thick are scaltered throughout the pelitic schist. Out. crops of graphitic schist may be bold and well jointed or subdued and covered with thin slabby talus, de. pending on the relative abundance of quart's. Graphitic schist consists of quartz + muscovite + graphite \pm phengite \pm talc \pm albite \pm chlorite \pm calcite, and trace amounts of splene. Muscovite-phengile is universally 
present, and occasionally relted masses of talc(?) are observed in graphitie schist associated with known ore horizons. Albite, when present, occurs as porphyto. blasts that have totaliy or partially replaced the other minerals. Minor calcite and chlorite occasionally are present in albite-bearing graphitic schist.

North of VABM! Ruby some schist horizons have enough calcite to be designated calcareous schist. These rocks are essentially chlorite-muscovite-quartiz schist that contains several percent calcite. They tend to be associated with thit, discontinuous marble units.

A few pelitic schist intervals immediately north of VABM Ruby are composed of white to greenish-white. intensely crenulated, quarb-muscovite talc schist. Fine. to medium-grained quartz and muscovite-phengite dominate this white schist. The presence of tale is indicated by a slight greasy feel on schistosity surfaces and by felted aggregates of a very fine-grained phyllosilicate occasionaliy observed as patches associated with muscovite. Minor albite, pennine, and calcite are occasionally presest in the white sehist and oceur late in its paragenesis. Sphene is present in trace amounts.

Ciren and white chlorite-muscovite-albite-quartz schist containing abundant poikiloblastic albite porphyroblasts crops out on the north end of Ruby Ridge. These rocks, which may be younger than the Pricambrian("?) pelitic rocks to the south, form part of a Paleozoic sequence continuing to the north.

\section{MARBLL}

Discontinuous marble lenses up to $300 \mathrm{~m}$ thick form a conspicuous but minor part of the rock assemblare near VABM Ruby. Nore continuous beds of marble up to $440 \mathrm{~m}$ thick are found along the north part of the ridge and appear $w$ be the southem edge of a major Paleozoic carbonate terrane that continues to the north (pl. 1).

The marble is gray weathering, gray on a fresh surface, and ranges from fine to medum-grained crystallo. blastic marble to thinly laminated, highly contorted schistose marble with an appreciable amount of silicate minerals. The latter lithology represents a transition from calcareous schist to marb]e. The marble consists dominantly of calcite, but minor quartz grains are scattered throughout, as are chlorite and muscovite. Sparse, irregular porphyroblasts of albite are present in some specimens. The marble lenses probably represent premetamorphic limestone beus.

\section{ML'TABASITE:}

Greenstone lenses are prominant along Ruby Ridge, especially near VABM Ruby (fig. 2) and in the tec. tonically thickened zone near peak 3870 (pl. 1). The metabasite forms lensoid pods and layers up to $500 \mathrm{~m}$ thick and several hundred meters long parallel to the

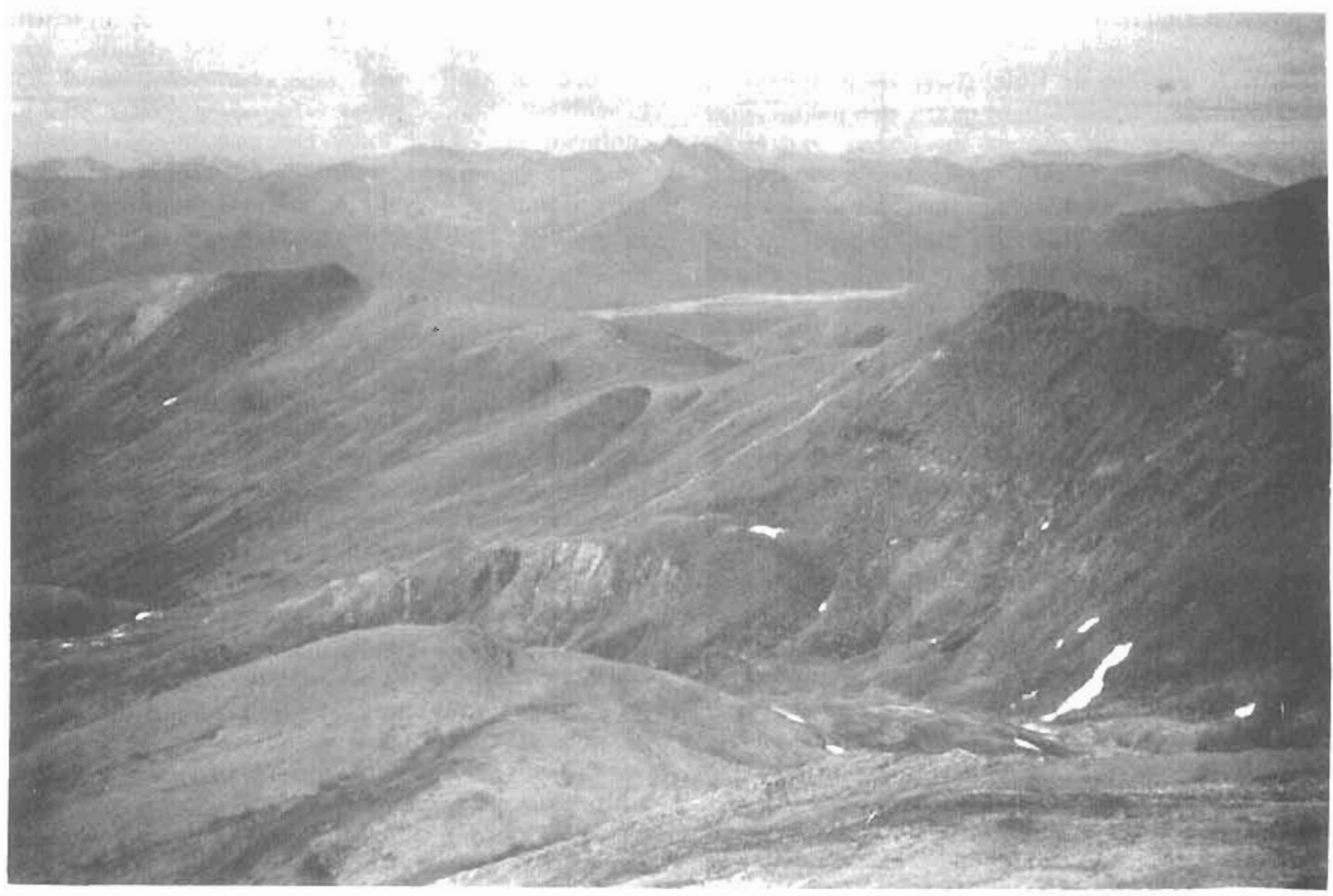

Figure 2, Looking northwest from VABM Ruby. Dark areas are glaueophane-bearing metabasite. 
dominant follation $\left(\mathrm{S}_{1}\right)$; it rarely occurs as bodies up to several meters thlck that cut across the dominant foliation, Exposures range from mitisive, jointed, angular outcrops surrounded by large, blocky boulders to wollpoliated, schlstose-slabby outcrops. The metabasite interval on the crest of Ruby Rldge $1.7 \mathrm{~km}$ north of VABM 3870 has ollow structures. The parent material of the metabasite probably consisted of basalt nows and gabbroic intrusions (table 1 ).

There is a continuous variation betweon massive, coarse-gralned, glaucophane-benting metabasite and occasionally follated, itne- to mediun-grained greenstone with greenschist-facies mineral assemblages (figs. 3,4 , and 5 ), but the two end members will be described separately.

\section{GLAUCOPHANE-BEARING METABASITE}

These rocks are generally massive with no apparent schistosity and form prominent rioges (fig. 2). Fresh samples are blue to bluish green, with is coarse-gralned, poikioblastic granular texture highilghted by reddishbrown garnets that stand out in reliep on weathored surfaces. The absence of schlstosity, whlch is unusual Por glaucophane schlst, appears to be due to the lack of penetratlve deformation. However, a crude follation was observed in a lew partially retrograded rocks and appears to be defined by mherals such as chlorlte, actinolite, and white mlea that crystallized during the later greenschist-Pacies event. A notable exception is a motabasite near the axls of the Kalurivik Arch that has a well-defined schistosity deflned by the parallel alignment of subldloblastic glaucophane prisms.

The main metamorphic minerals present in glaucophane-bearing metabasite are garnel, glaucophane, epldote, sphene, rutile, chlorite, and white mica. This

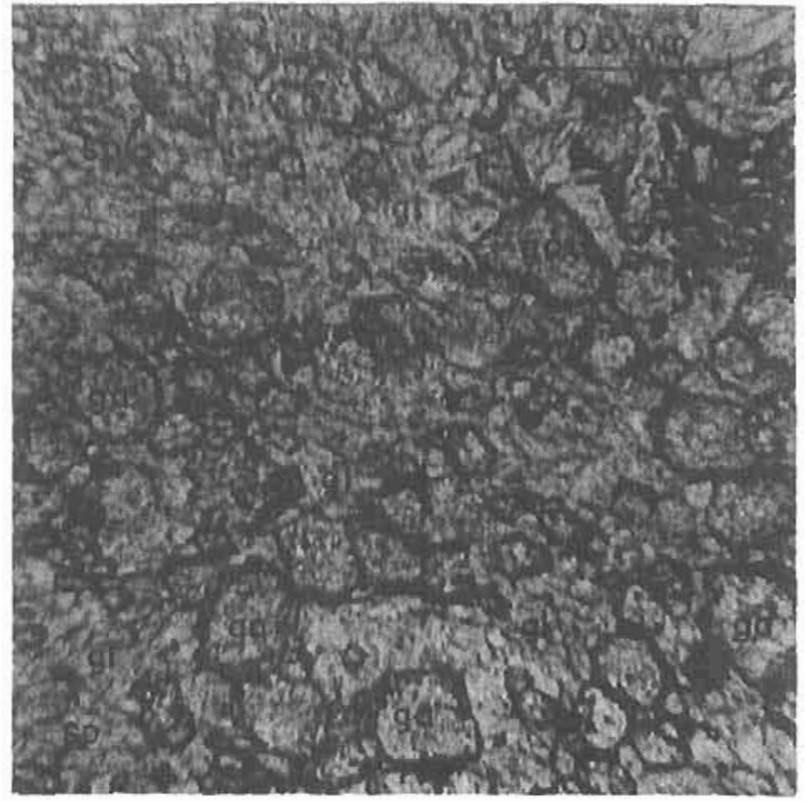

Figure 3. Photomicrograph of garnet-glaucophane metabasite. ga - garnet, gl - glaucopbane, sp - sphene.

mineral assemblage is evidence that the earliest metamorphism to affect the schist belt was of the blueschist Pacies.

Garnet, which makes up from 10 to 60 percent of these rocks, occurs as pinkish-brown porphyrobiasts ranging Prom 0.1 to $1.5 \mathrm{~mm}$ in diameter (fig. 3, cover photograph) and commonly exhibits irregular, chlorite. filled fractures. Garnet exhibits all degrees of retrograde metamorphism, from thin chlorite jackets to small islands of garmet that have been completely en-

Tabie 1. Che mical analyses (in weight-percent) of metaigneaus racks on Ruby Ridge (USGS rapid-rock analyses).

\begin{tabular}{|c|c|c|c|c|c|}
\hline & \multicolumn{2}{|c|}{ Metafelsite } & \multicolumn{3}{|c|}{ Metabasite } \\
\hline & $\begin{array}{c}\text { Sample } \\
\text { 79RRI9f } \\
\text { (Locality 1) }\end{array}$ & $\begin{array}{l}\text { Sample } \\
7 \text { 9RR20-3 } \\
\text { (Locallty 2) }\end{array}$ & $\begin{array}{c}\text { Sample } \\
\text { 73RR63f } \\
\text { (Locality 9) }\end{array}$ & $\begin{array}{c}\text { Sample } \\
\text { 78RRle } \\
\text { (Locality 4) }\end{array}$ & $\begin{array}{c}\text { Samplo } \\
7 \text { 3RR521 } \\
\text { (Locality 5 }\end{array}$ \\
\hline $\mathrm{SiO}_{2}$ & 70.9 & 72.1 & 47.4 & 50.7 & 49.6 \\
\hline $\mathrm{Al}_{2} \mathrm{O}_{3}$ & 13.6 & 14.0 & 1.6 .0 & 13.2 & 19.5 \\
\hline $\mathrm{Fe}_{2} \mathrm{O}_{3}$ & 1.4 & 0.68 & 1.9 & 4.5 & 3.3 \\
\hline $\mathrm{FeO}$ & 2.4 & 0.84 & 9.4 & 9.4 & 12.2 \\
\hline $\mathrm{MgO}$ & 2.6 & 0.67 & 7.1 & 0.1 & 5.5 \\
\hline $\mathrm{CaO}$ & 0.28 & 0.51 & 8.1 & 9.6 & 6.7 \\
\hline $\mathrm{Ng}, \mathrm{O}$ & 1.2 & 1.1 & 3.3 & 3.3 & 2.5 \\
\hline $\mathrm{K}_{2} \mathrm{O}$ & 5.8 & 7.0 & 0.12 & 0.62 & 0.06 \\
\hline $\mathrm{H}_{2} \mathrm{O}+$ & 1.6 & 0.97 & 3.2 & 0.99 & 1.7 \\
\hline $\mathrm{H}_{2}^{2} \mathrm{O}$ & $0.1 \mathrm{~J}$ & 0.00 & 0.18 & 0.00 & 0.09 \\
\hline $\mathrm{TiO}_{2}$ & 0.52 & 0.42 & 1.7 & 1.6 & 3.7 \\
\hline $\mathrm{P}_{2} \mathrm{O}_{5}^{2}$ & 0.15 & 0.09 & 0.23 & 0.15 & 0.39 \\
\hline $\mathrm{MnO}$ & 0.02 & 0.00 & 0.14 & 0.17 & 0.21 \\
\hline $\mathrm{CO}_{2}$ & 0.02 & 0.08 & 1.0 & 0.33 & 0.56 \\
\hline
\end{tabular}

l Concalny glucophano. 


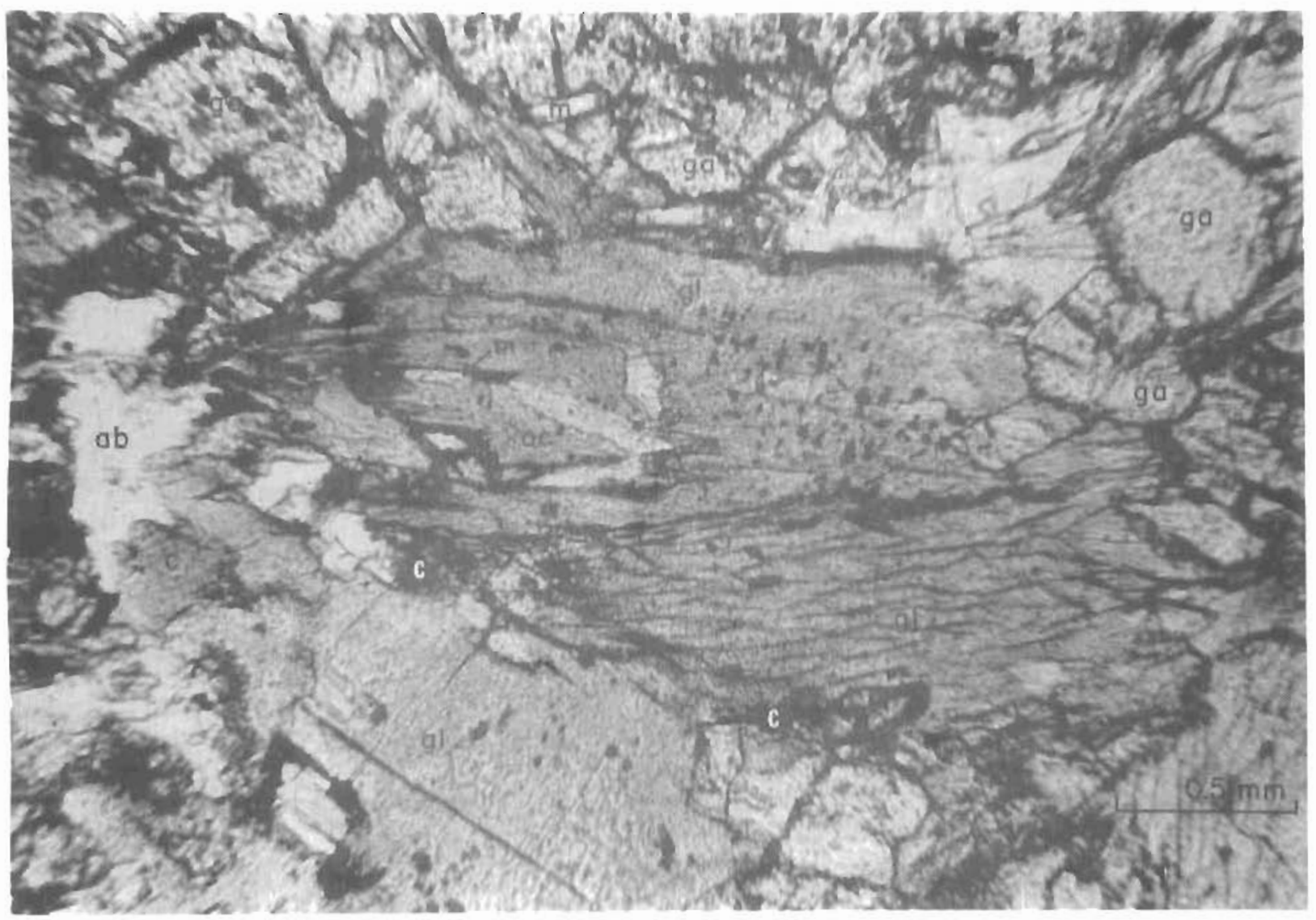

Figure 4. Photomicrograph of retrograded glaucophane-bearing metabasite. Actinolite (ac) is replacing glaucophane (gl). ga - garnet, ab-albite, $\mathrm{c}$ - chlorite, $\mathrm{m}$ - muscovite,

gulfed by chlorite.

Glaucophane (determined by X-ray diffraction) typically occurs as large pleochroic porphyroblasts up to $3 \mathrm{~mm}$ long. The glaucophane most frequently forms a directionless mosaic of decussate, subidioblastic prismatic crystals that surround garnet (fig. 3). Retrograde effects in glaucophane include the appearance of both motlled zones, in which the usual blue pleochroism gives way to the wholesale replacement by actinolite, and felted aggregates of chlorite and actinolite on grain margins (fig. 4). Actinolite does not appear to be in equilibrium with glaucophane, but rather is replacing it.

Epidote is the dominant epidote-family mineral in the glaucophane-bearing rocks, and commonly displays zoning from iron-rich cores to iron-poor rims. One sample contains both epidote and ctinozoisite, but the dinozoisite most likely formed later during overprinting by the greenschist-facies metamorphic event.

Sphene is present as a ubiquitous accessory phase and occurs as small idioblastic grains less than $0.1 \mathrm{~mm}$ long and in aggregates as large as $2.0 \mathrm{~mm}$ across (fig. 3). Rutile commonly occurs as cores in sphene euhedra, which appear to have retrograded to sphene during the greenschist thermal event.
White mica was determined to be paragonite on the basis of its low potassium content. Most of the chlorite found in these rocks has been produced by retrograde meiamorphism; however, a small portion may have been in equilibrium with the initial blueschist assemblage.

Trace to minor amounts of quartz and albite are present in some specimens and appear to be the earliest. formed minerals. Therefore, this albite formed earlier than that in the felsic schisis.

Coarse-grained jadeite occurs in metabasite at one locality on the south slope of VABM Ruby (pl. 1). Jadeite and glaucophane in this rock are cut by a later foliation. Jadeite may have been more common in metabașite prior to greenschist facies overprinting.

\section{GREENSCHIST}

Metabasite with greenschist-facies mineralogy is light grayish green to dark olive green on fresh surfaces and varies from massive, fine-grained greenstone to foliated, medium-grained greenstone. The dominant minerals in these rocks are actinolite, epidote, albite, chlorite, and commonly garnet. (fig. 5).

Actinolite typically occurs as pleochroic porphyro- 


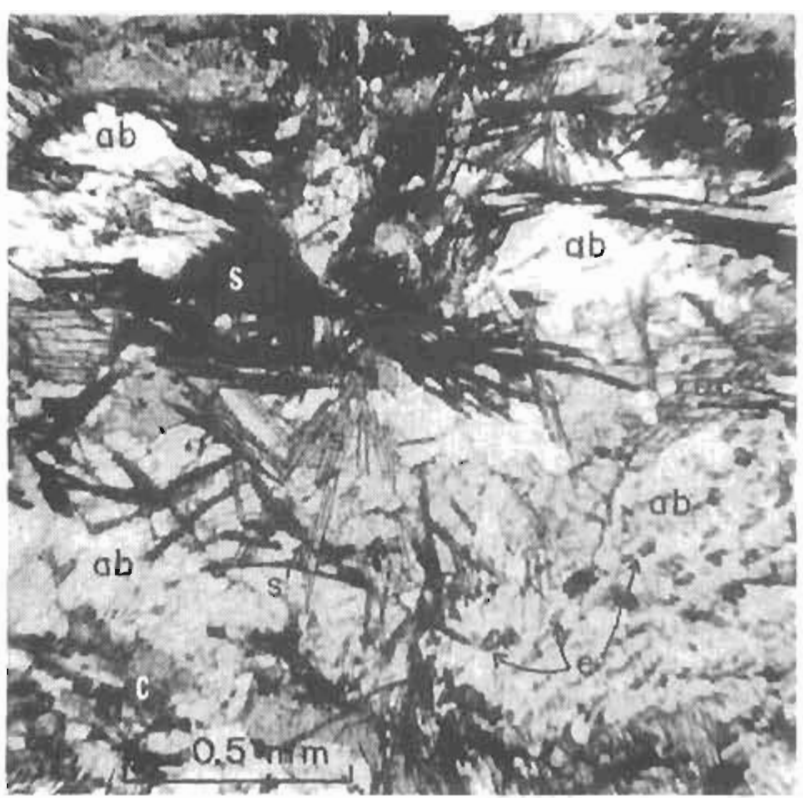

Figule 5. Photomicrograph of greenschist metaisasite. ab-albite, s - stidpnomelane, $c$ - chlorite, e epuidote.

blasis, or as a felly aggregate that accounts lor 20 to 60 percent of the rock.

Epidote or clinozoisite typically occurs as idioblastic to subidioblustic prisms 0.1-1.0 $\mathrm{mm}$ long elongated along their b axis and parallel to the plane of foliation. As in glaucophane-bearing metabasite, epidole is gen. erally zoned from iron-rich cores to iron-poor rims. The zoning is thought to be due to the increase in crystallization temperature associated with greenschistfacies metamorphism that alfected earlier formed epidote.

'Two generalions of garnet are recognized in these rocks: (1) that formed dituing the blueschist facies metrimorphic cvent., which is ritrograded and occurs as small xenoblasts surrounded hy chlorite (fig. 6), and (2) Lhat formed during the subsequent greenschistlacies event, which occurs as idioblastic porphyroblasts and is not altered to chlorite.

Albite is present as helicitic untwinned xenoblasts up to $1.5 \mathrm{~mm}$ in diameter. Weakly pelochroic chlorite occurs as interstitial laths and aggregates located belween larger amphibole, clinozoisite, and garnet grains.

Minor mincrals commonly present in these rocks are spherse, quartz, calcite, stilpnomelane (fig. 5) and biolile. Sphene is the most common nonopaque accessory mineral and occurs as euhedral grains, in trains, or as aggregates. Quarly occurs as early-formed, clear, equanl, or lisulicular grains, whereas sphene and calcite formed late in the paragenesis of these rocks. Rare stilpnomelane occurs as radiating aggregates associated with calcitu on the south part of Ruby Ridge, and incipirnt biolite is seen forming from chlorite in a few samples from the north end of the ridge.
In most cases, greenschist-facies metabasite was previously metamorphosed to high-lemperature blue. schist facies, allhough it is difficult to distinguish rocks that are retrograded blueschists from greenschist-facies metabasite formed directly from gabbro or basalt. In many specimens, however, there is excellent textural and mineralogical evidence for formation of greenschists from blueschists (fig. 1). The absence of biotite in blueschist-lacies rock; is diagnostic, as previously noled by Taylor and Coleman (1968). However, on the north end of Ruby Ridge, where greenschist-facies metanorphism was most intense, biotite appears as a stable phase in synkinematic assemblages.

The first minerals to be allacked by the relrograde metamorphism are glaucophate and garnet. Glauco. phane is usually replaced by ale-green amphibole that mimies original glaucophane textures (fig. 4). Garnel alters to chlorite, which forms pseudomorphic aggregates after the original porphyroblasts (fig. 6). Epidote in: some of the blueschist astomblages has under. gone a more sublle transition. South of VABM Ruby epidote prains are commonly zoned from iron-rich cores to jron-poor rims (clinozoisite in many instances). North of prak 3870 clinozoisite is the stable epidote mineral and is usually found as large porphyroblasts. Epidote rarely occurs as inclusions in garnet or albite.

\section{ME'TAFELSITE}

Two east-trending bands of folshe sthist are present just north and northeast of VABM Ruby (pl. 1). The occurrences are separated by intervening pelitic schist. metabasite, and a thrust fault. The northern relsic schisi was probably once laterally continuous with the southen sequence. Most felsic schist is light gray on both tresh and wealhered surfaces and forms low angular ridges to subdued and rounded outcrops mantled with slabby talus. A distinclive feature of some outcrops is the presence of slightly elongate, curved slabs and prisms of rock that resemble the sinuous columnarjointing characteristics of small felsic volcanic domes. The relsic schist commonly contains quartz + microcline + mascovite-phengite \pm bintite + albile \pm lalc(?) \pm chlorite \pm clinozoisite-epidote + sphene $\div$ apalite + zircon + calcite. Biotite or microcline or buth are characteristic of this schist. When present, microcline appears to be recrystallized premetamorplic K-leldspar phenocrysts. The microcline crystals are often euhedral or are angular fragments of euhedral crystals, and deep sinuous embayments randomly penetrate the megacrysts. Some specimens show foliation bending around microcline, while in a few cases foliation seems little altered by the presence of megacrysts $1.5-2.0 \mathrm{~cm}$ across. Some intervals are markedily blastoporphyritic with megacrysts of partially resorbed bluish quartz as well as K-feldspar. Except for anhedral form and smaller size, quartz megacrysts closely resemble micro. cline megaciysts. The quartz and inicrocline megacrysts 


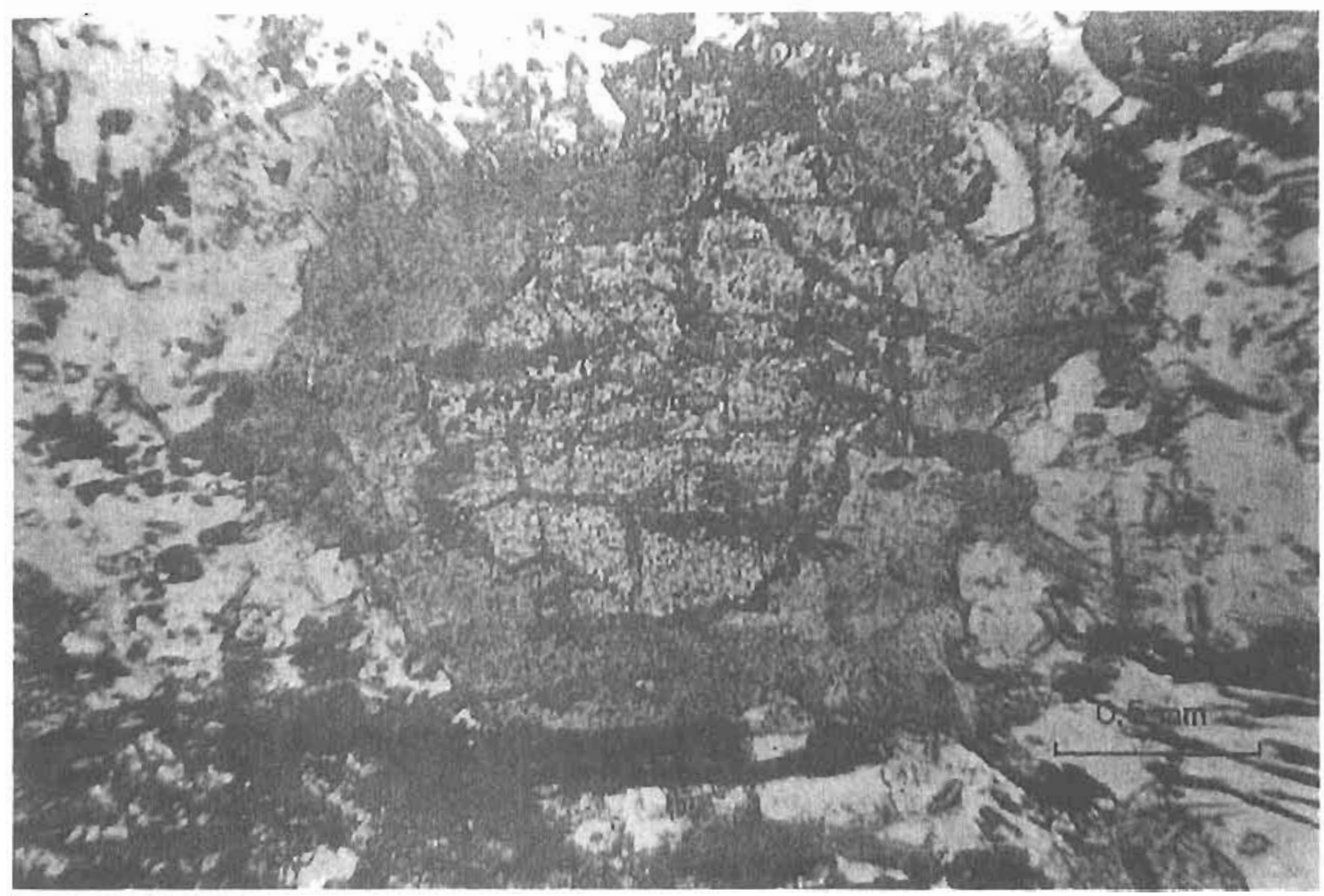

Figure 6. Photomicrograph of greenschist metabasite showing chlorite (c) forming from garnet (ga).

are most likely relict phenocrysts of quartz and $K$ feldspar, which suggests that the metafelsites were originally felsic hypabyssal or volcanic rocks.

Near VABM Ruby fine-grained brown biotite is usually present. as a minor accessory (1-3 percent). These rocks have bulk compositions analogous to potassic rhyolite or granite (table 1). Incipient; biotite is also found in pelitic schist adjacent to these units, and $I l$ is possible that these two occurrences of biotite are related. Carden and Forbes believe that the metafelsites are synkinematic hypabyssal rocks that were emplaced during a younger metamorphic event, carrying: their own thermal perturbation with them at the time of intrusion. The incipient biotite in the adjacent rocks would then be related to hornfelsing at the time of intrusion. Wiltse and Gilbert believe that the metafelsite constitutes a metamorphosed submarine volcanic sequence of felsic lavas and tuffs. Wiltse (1975) postulated that the biotite in the schist surrounding the most quartzose feldspathic units was due to the high potassiurn content of metamorphosed pelitic sediments that had incorporated tuffaceous volcanic debris. This view rejects any significant hornfelsing.

Porphyroblasts of albite are rare in the metafelsite and are paragenetically late. Epidote and calcite oc. caslonally occur in rocks containing albite. Sphene, apatite, and zircon are present in trace amounts. A few felsic schists contain 1.2 percent pyrite in 6 - to $12-\mathrm{mm}$. wide cubes.

\section{SOITHWESTERN END OF RUBY RIDGE}

On the soutlowestern end of Ruby Ridge near peak 2100 is a sequence of massive, weakly metamorphosed greenstone and thinly bedded, fine-grained gray marble. Intercalated with these rocks are minor amounts of phyllite, calc-phyllite, and black chert. Thuse rocks strike approximately east-west and dip south under the Ambler Lowland.

The greenstone, which makes up 60 percent of the rocks near peak 2100, is very thlokly layered and dlsplays schistosity onty along widely spaced shear surfaces. In thin section a relict igneous mineralony and texture is preserved. Some samples have a tuffaceous texture, The greenstone contains relict primary plagloclase, pyroxene, and glass, which are cominonly altered to epidote and chlorite. These rocks probably were metamorphosed in the prehnite-pumpellyite facies or lowest part of the greenschist facles.

Marble, which make's up 30 percent of the rocks near peak 2100, is thin, flaggy, and very weakly metamorphosed (fig. 7). Fine-grained calcite is the domlnant minersl phase, and there are minor amounts of quartz and sericite.

Medium. to dark-gray phyllite and calc-plyyllte crop out on Ruby Ridge near peak 2060. These rocks ure composed dominanlly of quartz, sericite, and plagloclase. Some specimens contain enough calcite to freely effervese in dilute hydrochloric acid. 


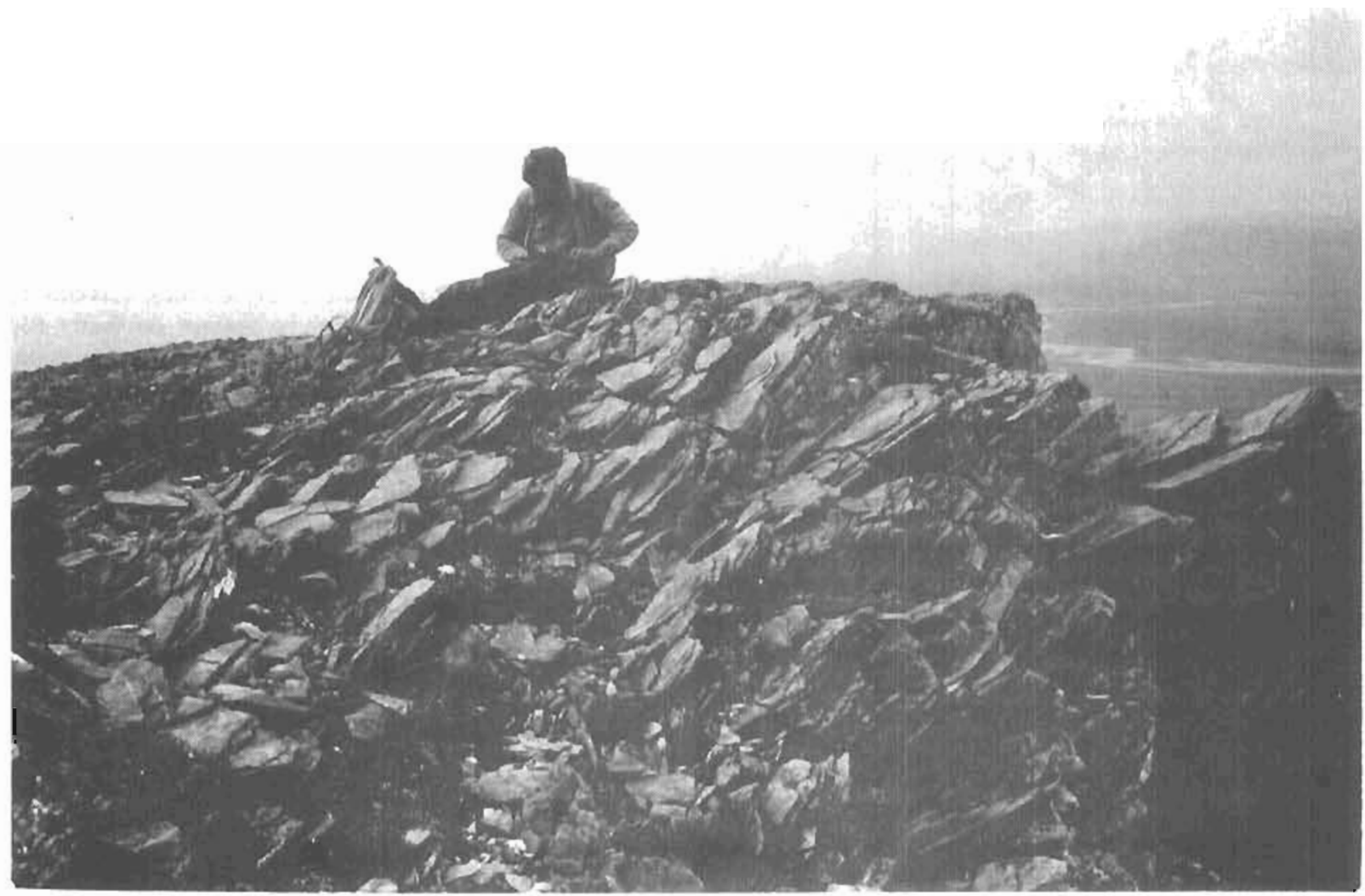

Finure 7. Photagraph of south-dipping marble $0.6 \mathrm{~km}$ west of peak 2100 on southwestern end of Ruby Hicisa.

\section{STRUCTURE}

\section{INTRODUCTION}

The structure of rocks on Ruby Ridge reflects at leasi two episodes of dynamic metamorpbism and penetrative deformation. These events were superimposed on a preexisting basement terrane metamorphosed, in part, to blueschist facies. At only one locality wert dymamic features formed during the early, blueschist metamorphic event observed, but. it. is likely that early dynamic features are largely masked by later events. The first noticeable major dynamic event gen. exated recumbent folds, thrust, faults, and crystallization foliation. The second dynamic event generated open to subisoclinal folds and ship cleavage, but was not accompanied by extensive recrystallization.

\section{EARLY ISOCEINAL FOLDS AND THRUST FAULTS}

The first dynamic event is characterized by isoclinal to subisoclinal folds $\left(F_{1}\right)$ overturned to the north (fig. 8) and is accompanied by synkinematic reerystallization and scgregation of me tasedimentary rocks into mica-rich and quartz-rich layers $\left(S_{1}\right)$. Earier $S_{0}$ layering is generally transposed and parallel to $S$, folialion. Iso. clinal- and subisoclinal-fold wavelengths vary from microscopic to several hundred meters. Near peak 3870 is a tectonically thickened zone where numerous recumbent folds are piled on one another (fig. 9). This zonc of thickening. or protonappe development, probably reflects movement northward. Large isoclinal folds are also present $2.0 \mathrm{~km}$ north and south of VABM Ruby along Ruby Ridge.

The northwest-trending overturned antiform and synform on the north end of Ruby Ridge were probably formed at the same time as the isoclinal folds to the south. These folds are less closed than isoclinal folds to the south, and suggest that $F_{1}$ deformation was less intense to the north.

Scattered $F_{1}$ fold axes suggest an east-west trend for $F_{1}$ folds (ifg. 10). However, $S$, foliation on both the north and south limbs of the Kalurivik Arch defines vague girdles that most likely are due to variable limbs of $\mathrm{F}_{1}$ folos, especially in the zone of tectonic thickening (pl. 1, fig. 11a-c). F, fold axes calculated irom both girdies were rotated by uniolding the Kalurivik Arch and suggest a prearch $F_{1}$ trend of $N \cdot 72^{\circ} \mathrm{W}$. and a plunge of $16^{\circ}$ (fig. 11a,b).

Thrust fauls associated with subisoclinal-isoclinal 


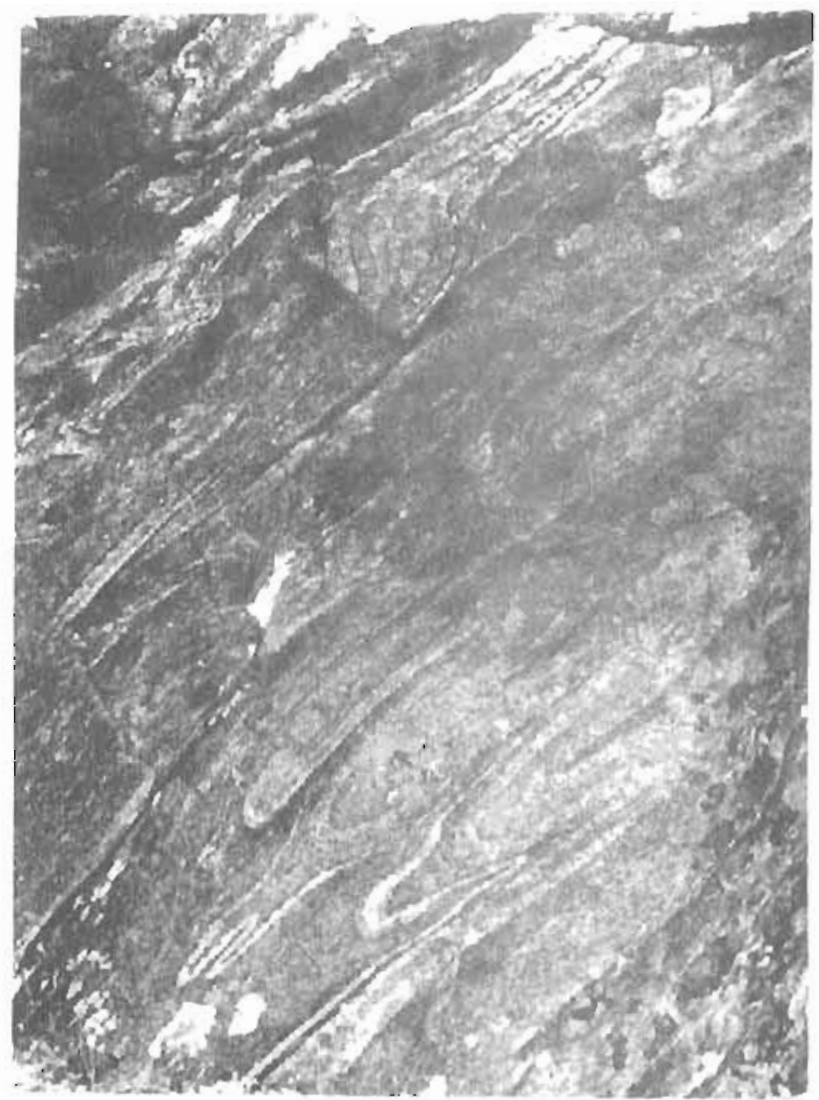

Figure 8. Isoclinal F, fold.s mtar VABM Ruby. folds are present near VABM Ruby, and probably occur eisewhere, especially near peak 3870. The thrust surfaces are not conspicuous and are discovered only by detailed mapping of adjacent lithologic units (fig. 12). The two thrust faults north of VABM Ruby dip south about $35^{\circ}$, subparallet to $S_{1}$. Displacements along these faults is unknown, but are probably tens to hundreds of melers. An overturned antiform and synform are present just beneath the eastern part of the upper thrust foult,

The Walker Lake fault mapped to the east (Pessel and others, 1973b) projects toward the norlh end of Ruby Ridge (pl. 1), but no evidence of this fault was observed. The Walker Lake fault may be present on Ruby Ridge, juxtaposing similar rock types, or it may merge into a fold system along strike,

\section{LATER FOLDS AND FORMATTON OF KALLRIVIK ARCH}

A later, primarily dynamic metamorphic event also affected the Ruby Ridge area. This event is char acterized by open to subisoclinal folds $\left(F_{2}\right)$ ranging from microseopic crenulations to folds with wavelengths of several meters. These folds are present all along the ridge, but appear slightly more intense to the north. $F_{2}$ fold axes trend approximately east-wist, with a preferred orientation of S. $78^{\circ} \mathrm{E}$. and a plunge of $8^{\circ}$ (fig. 13).

A slip cleavage $\left(S_{2}\right)$ is commonly developed parallel to $\mathrm{F}_{2}$ axial surfaces and dips gently northward (lig. 14). This cleavage is well developed north of the Kalurivik

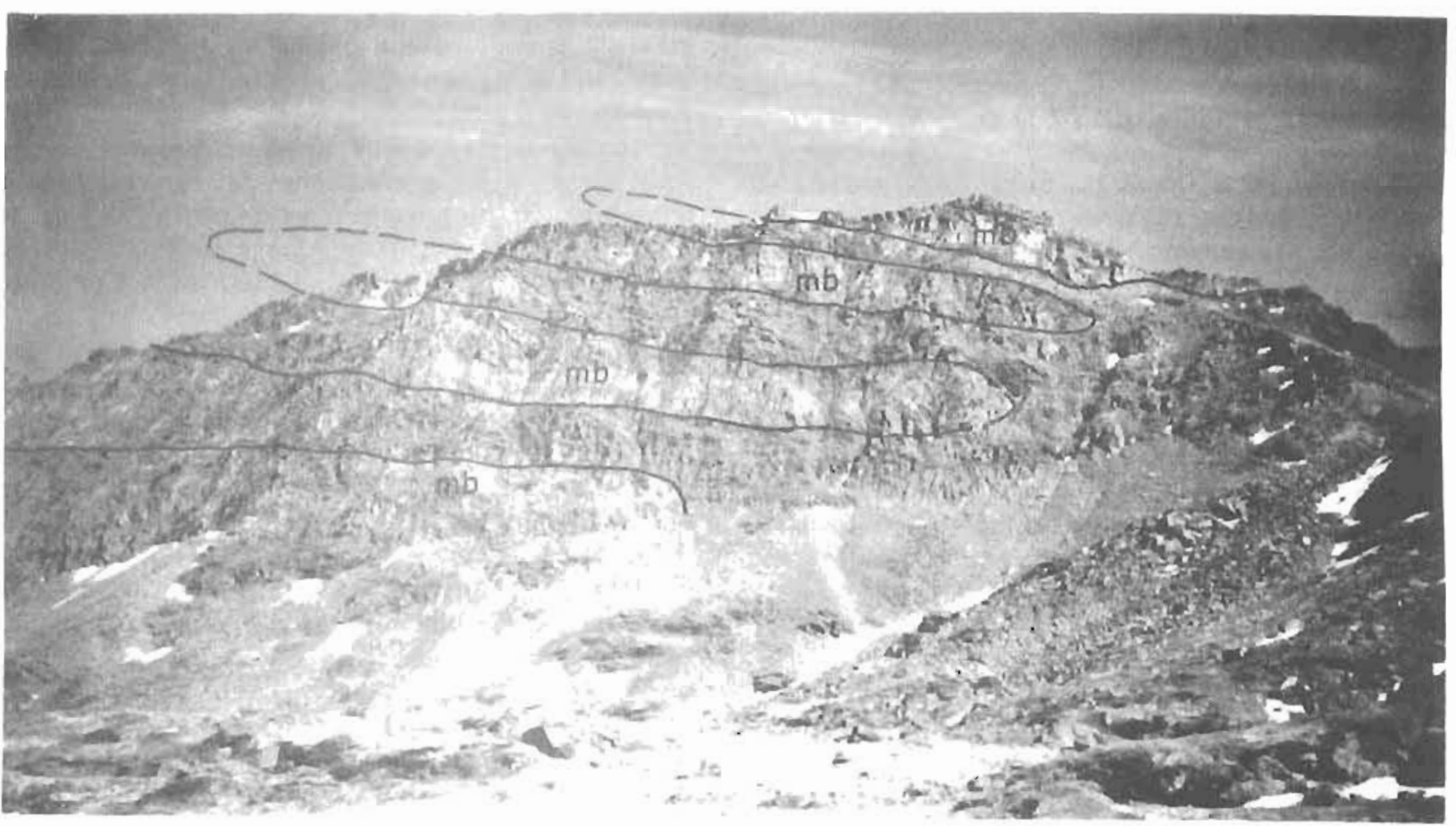

Figure 9. Recumbent isoclinal folds on cliff west of peak 3870 . mb - metabasile. 


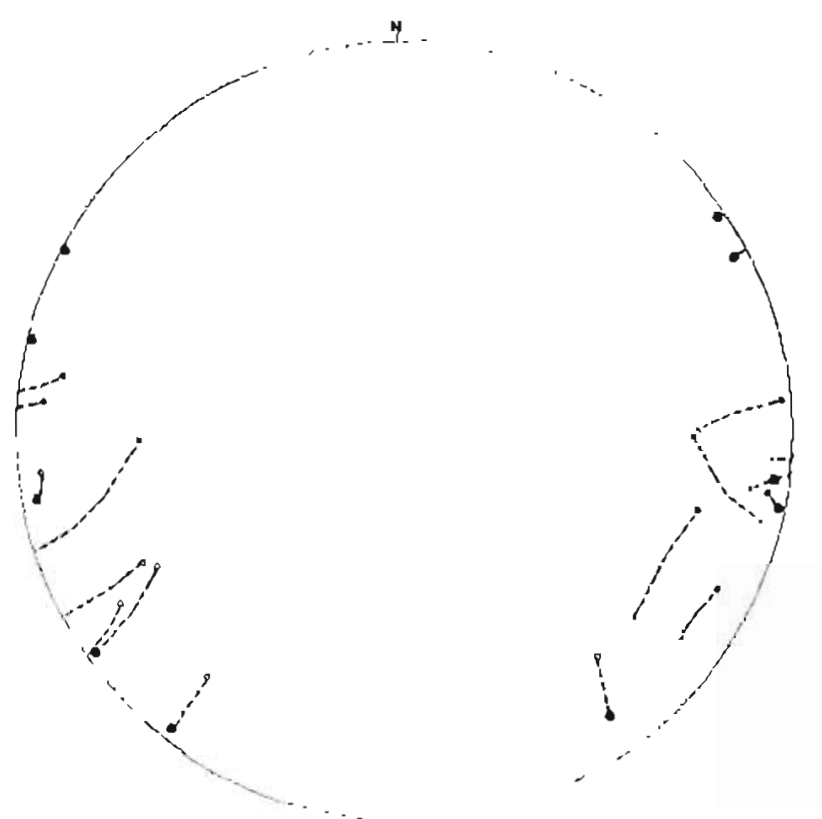

Figure 10. Lower hemisphere equal-area plot of 17 $F_{1}$ fold axes. $x$ - from morth of Kalurivik Arch. o from south of Kalurivik Arch. Prearch orientation determined by rotating attitude to horizontal. o prearch $\mathrm{F}_{1}$ orientation north of Kaluxivik Arch, - = prearch $F_{1}$ orientation south of Kalurivik Arch.

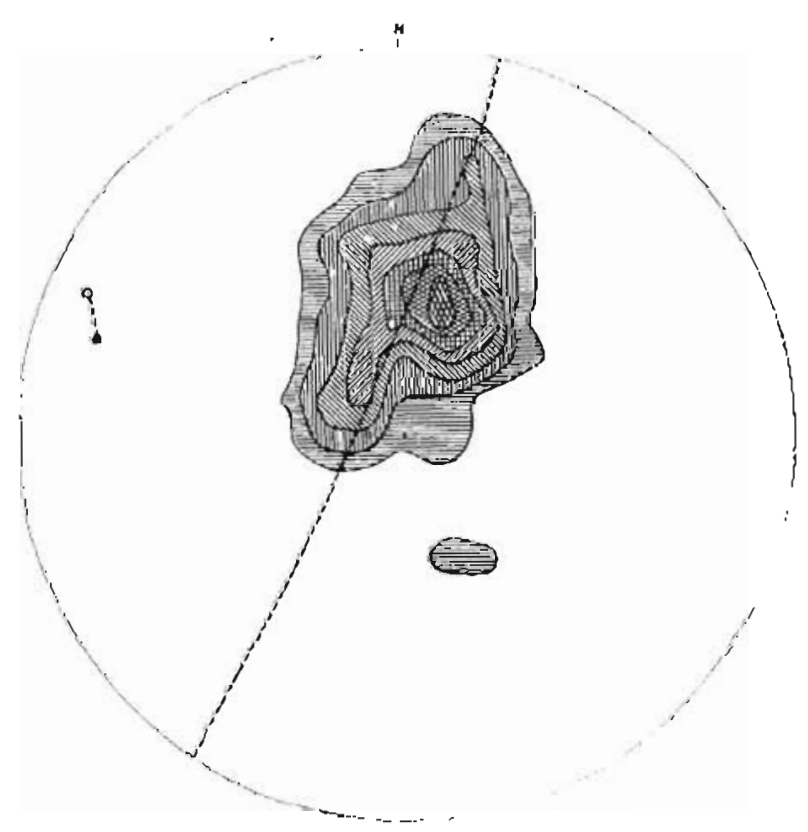

Figure 11b. Lower hemisphere equal-arca plot of 127 poles to $S_{1}$ foliation south of Kalurivik Arch along Ruby Ridge. Contour interval at $2,4,6,8,10,12$, and 14 percont per 1 -percent area. General $\mathbf{F}_{1}$ fold axis (open circle) calculated from vague girdle lying along dashed small circle. - general prearch $F_{1}$ fold axis determined by rolating Kalurivik Arch to horizontal.

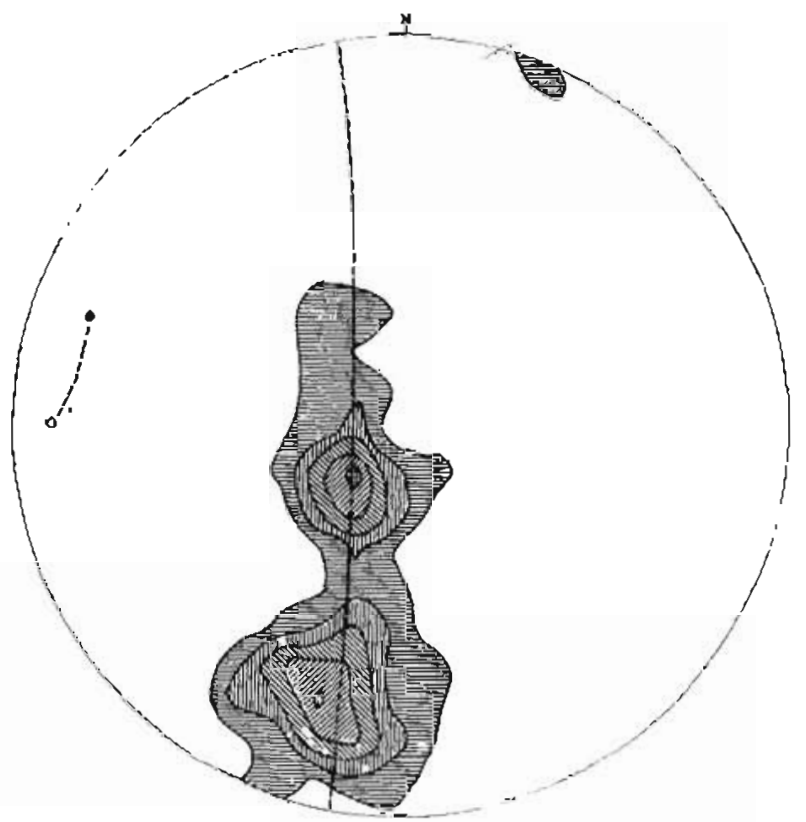

Figure 11a. Lower hemisphere equal-area plot of 167 poles to $s_{1}$ foliation morth of Kalurivik Arch along Ruby Ridge. Contour interval at $2,4,6,8$, and 10 percent per 1-percent area. General $F_{1}$ fold axis (open circle) calculated from vague girdle lying along dashed small circle. - general prearch $F_{1}$ fold axis determined by rotating Kalurivik Arch to horizontal.

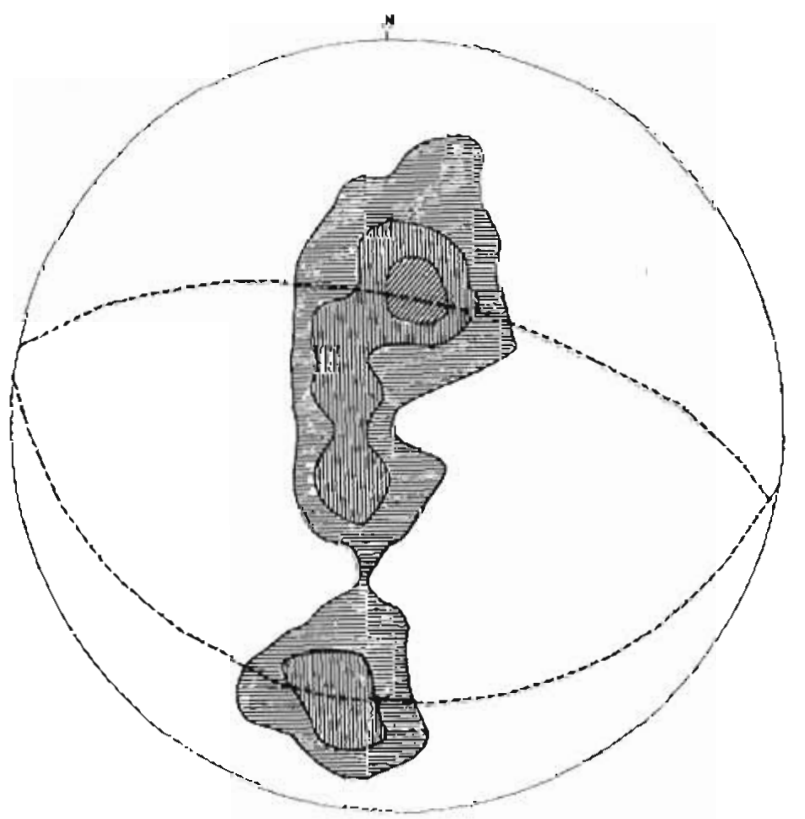

Figure 11c. Lower hemisphere oqual-aroa plot of 294 poles to $\mathbf{S}_{1}$ foliation along Ruby Ridge. Contour. interval at 2, 4, and 6 percent per 1-percent area, Dashed lines are goneral trace of north and south limbs of Kalurivik Arch calculated from $\pi$ diagram. Intersection of trace of $11 \mathrm{mbs}=$ calculated axis of Kalurivik Arch. 


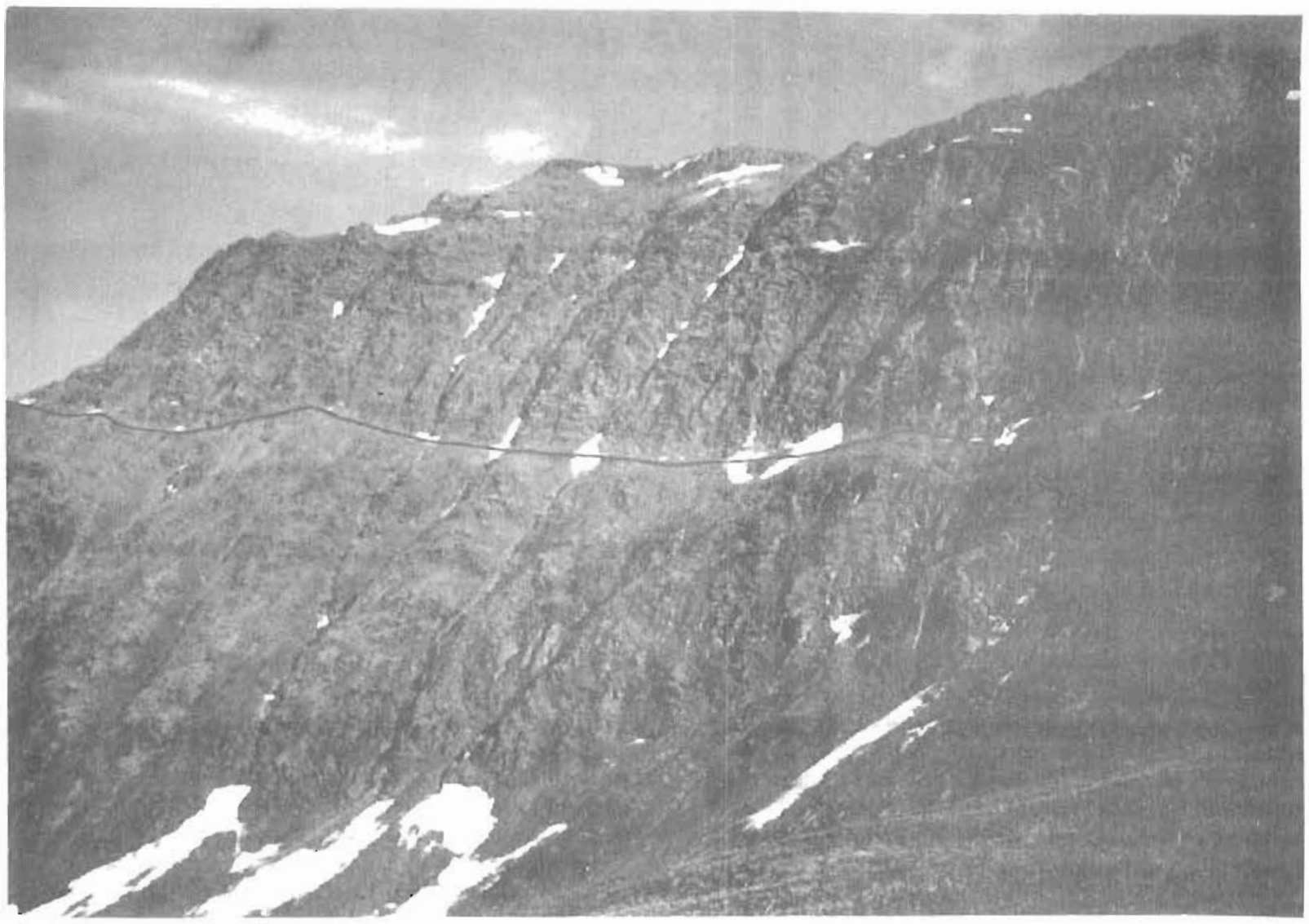

Figure 12. Trace of thrust fault on ridge northeașt of VABM Ruby N
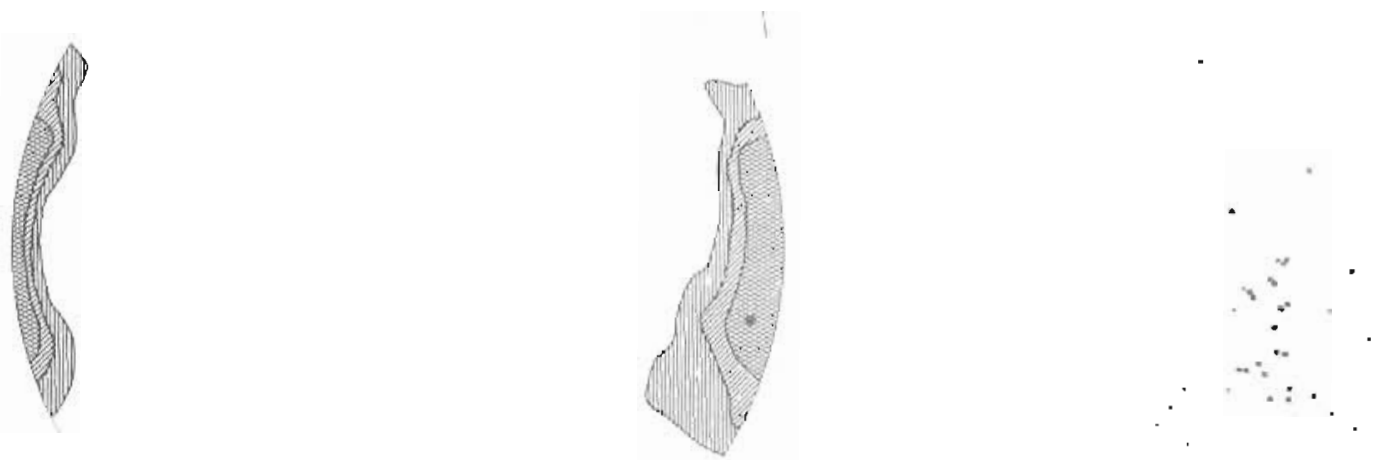

Figure 13. Lower hemisphere equal-area plot of $75 F_{2}$ fald axes along Ruby Ridge. Contour interval at 4 , 8, 12, and 16 percent per 1-percent area.
Figure 14. Lower hemisphere equal-area plot of 38 poles to $\mathrm{S}_{2}$ cleavage, - from north of Kalurivik Arch. $x$ - from south of Kalurivik Arch. 
Arch, while south of the arch it is commonly incipienl (fir. 15).

The Kalurivik Axch is an antiform that extends for at least. $62 \mathrm{~km}$ along the schist belt (Pessel and Brosge, 1977). Near Ruby Ridge the Kalurivik Arch is assymmetrical, deflecting major lithologic units $\left(S_{1}\right)$ moderately to the south and steeply to the north (fig. 11c). The arch may have formed at about the same time as the F' fold event, since the calculated axis of the arch (fig. $11 \mathrm{c}$ ) is nearly identical with the axes of $\mathrm{F}_{2}$ folds (fig. 1.3). On the other hand, $S_{2}$ cleavage is not affected by the arch and could have formed synchronous with of following the arching.

High-angle faults mapped in several places formed pither during the last major dynamic event or latey. on the north end of Ruby Ridge a northwest-trending high. angle fault truncates a marble interval and a ereenstone interval. Just north of peak 3870 a probable kigh-angle fault marks a major inflection of the Kalurivik Arch (pl. 1). Just north of VABM Ruby several high-angle faults iruncate lithologic intervals (pl. 1). The direction of movement and displacement along these faults is moknown, but is likely a lew tens of meters. Similar faults are undoubtedly present elsewhere along Ruby Ridge.

\section{AEROMAGNETIC SURVEY}

Totalintensity magnelic data from the 1975 Alaska JGGS aeromagnetic survey (flown by Geometries, Inc.) were obtained with a continuous digital-recording proton magnelometer installed in a twin-engine fixed-wing aircraft. Flight paths were north-south, about $1.2 \mathrm{~km}$ apart, $330 \mathrm{~m}$ above ground level. Total magnetic intensity anomaly values over the study area vary from -150 gammas in the Anbler Lowland to +450 gammas in the Schwatka Mountains (fig. 16). Extensive linear zones of high intensity lie over the Cosmos Hills and the uplands of the Baird and Schwatka Mounkins. Broad east-west magnetic lows and highs occur over the southem portions of the schist belt. Flat magnetic lows occur over the majority of the Ambler Lowland. The dominant west-northwest regional magnetic trends are localiy deflected by northwest-southeast structural features suggestive of transcurrent. block movements (fig. 16). Magnetic features are not appreciably influenced by topography and are superimposed on a negative southwestward regional gradient of about 2.7 gammas/ $\mathrm{km}$, If remanent magnetization is present, body size, shape, and dip and magnetization direction are in. separable until rock susceptibility values are determined.

In the Cosmos Hills are a sharp, high-amplitude magnetic signature associated with serpentinite, metaconglomerate, and metabasalt, and moderate to broad magnetic highs and lows associated with phyllite (fig. 16). Metamorphic and volcanic rocks of the schist beit have a subdued and variable magnetic response but show a strongly developed regional magnetic strike parallel to tectonic trends (fig. 16).
A conspicuous feature in the study area is the lack of magnetic anomalies greater than 40 gammas over the southern Brooks Range copper deposits. Truncation of magnetic anomalies suggest major basement laults or near vertical contacts at depth between the Cosmos Hills and the schist belt. In addition, a major change in magnetic gradient. indicates a contrast in basement lithology along the south margin of the schist belt (fig. 16). Superimposed on these magnetic features is a linear zone of nearly flat gradient that reflects the major topographic depression of the Ambler Lowland.

The geologic and geophysical contrasts between the schist belt and Ambler Lowland-Cosmos Hills area suggest. that a major tectonic boundary just north and parallel to the Ambier Lowland may juxtapose the weakly metamorphosed Paleozoic bașalt and carbonate Lerrane to the south against polymetamorphic: Precambrian and younger(?) rocks of the schist belt to the north (fig. 17). If such a tectonic boundary exists, it probably crosses Ruby Ridge $3.5 \mathrm{~km}$ southwest of VABM Ruby.

A narrow magnetic high is associated with the Walker Lake lineament. (Fritts and others, 1972) and trends from Walker Lake in the east to where it broadens westward near the Redstone River and truncates against. the

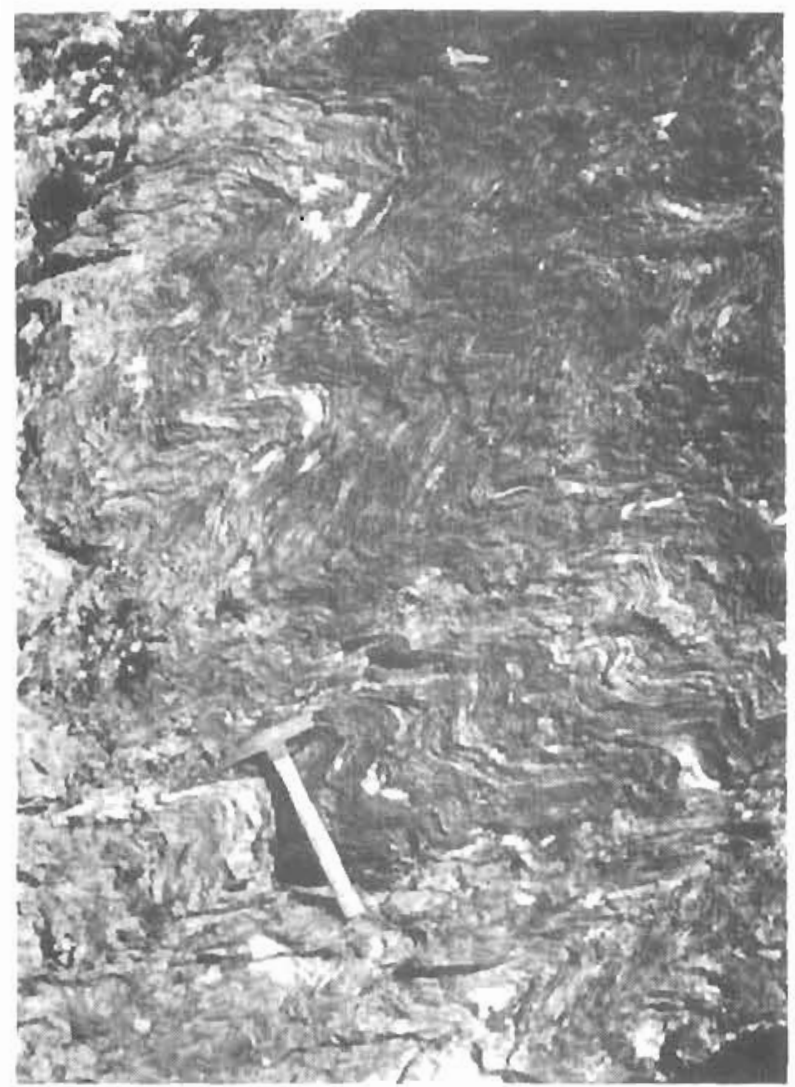

Figure 15. Photograph of $F_{2}$ folds and $S_{i 2}$ cleavage (parailel to hammerhead). 
$157^{\circ} 30^{\prime}$

$157^{\circ} 00^{\prime}$

$156^{\circ} 00^{\prime}$

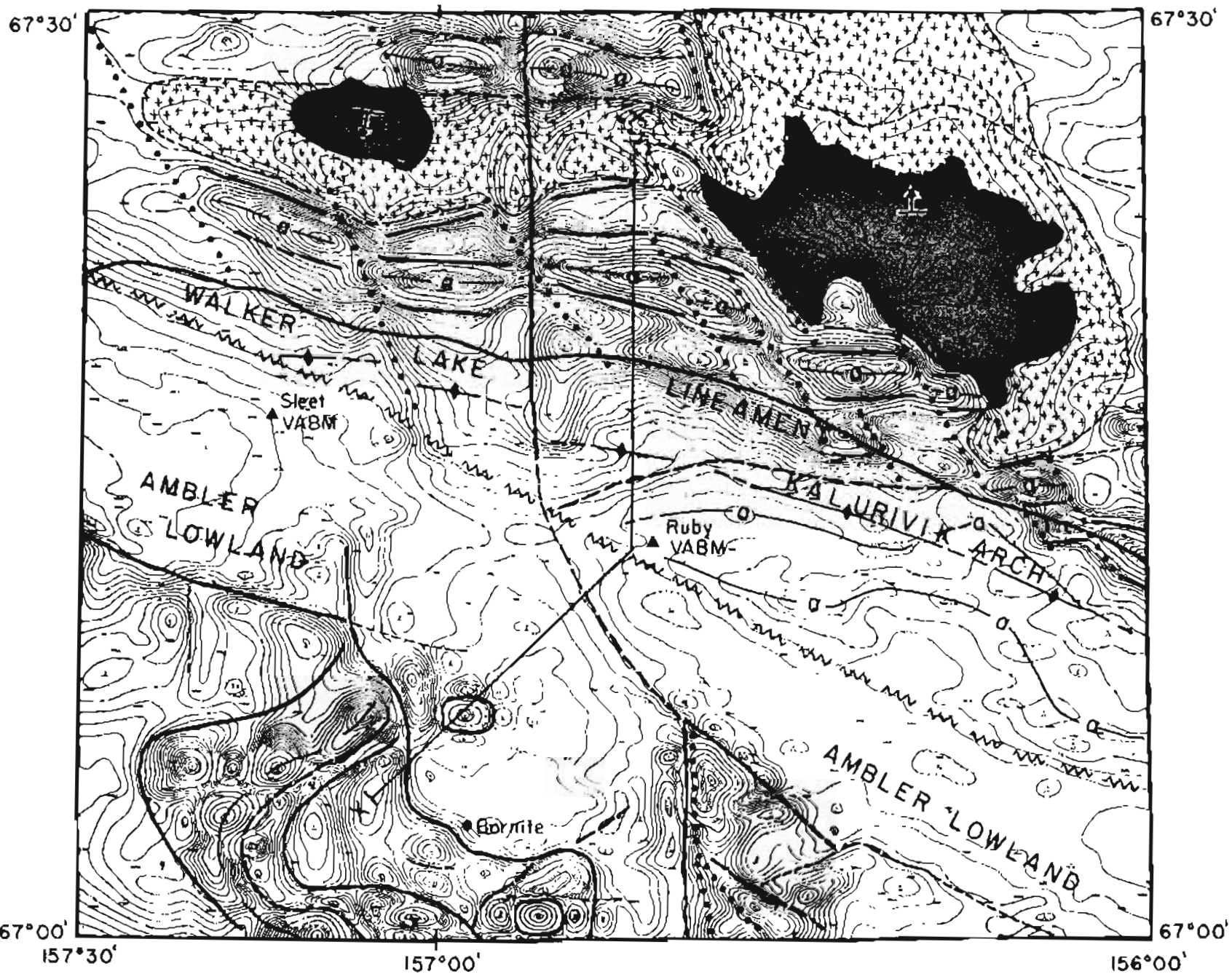

PXPLANATION

MAGNETIC DATA

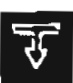

Granluc intrusion, 由howing spparys dip

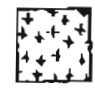

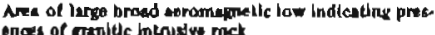
ances of grenitic intrusdy mact

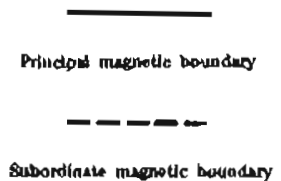

Subulued myoetie boundery

Mr w

Reglazel menetic dicoontinuity

0000000

Tenminadion or break in ruegnetle anomaly wend. probably cauced by menent laulunt

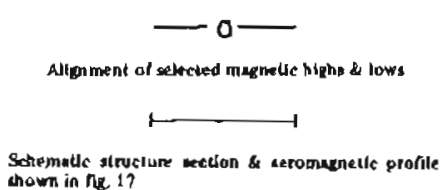

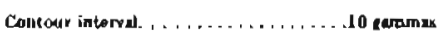
Dratum. . . . . . . . . . . . .56,380 gammas rlight ling epecing. . . . . . . . . 1,0 notled Hight wilsodo, . . . . . . . I, ODO fatt AQL Magnetic dedination. . . . . . . . . . . . . 230 Mapaetir indinsular. . . . . . . . . . . . . . 970 A reglond irend of 9.46 gammasionte North \& 2.25 eammas/mitie Dast wis memoyed wing the baps

Fown a prowesed by Geometrice 187.1.76

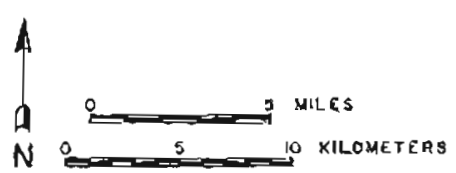

Figuye 16. Regional acxomagnetic features of area covered hy lig. 1. 

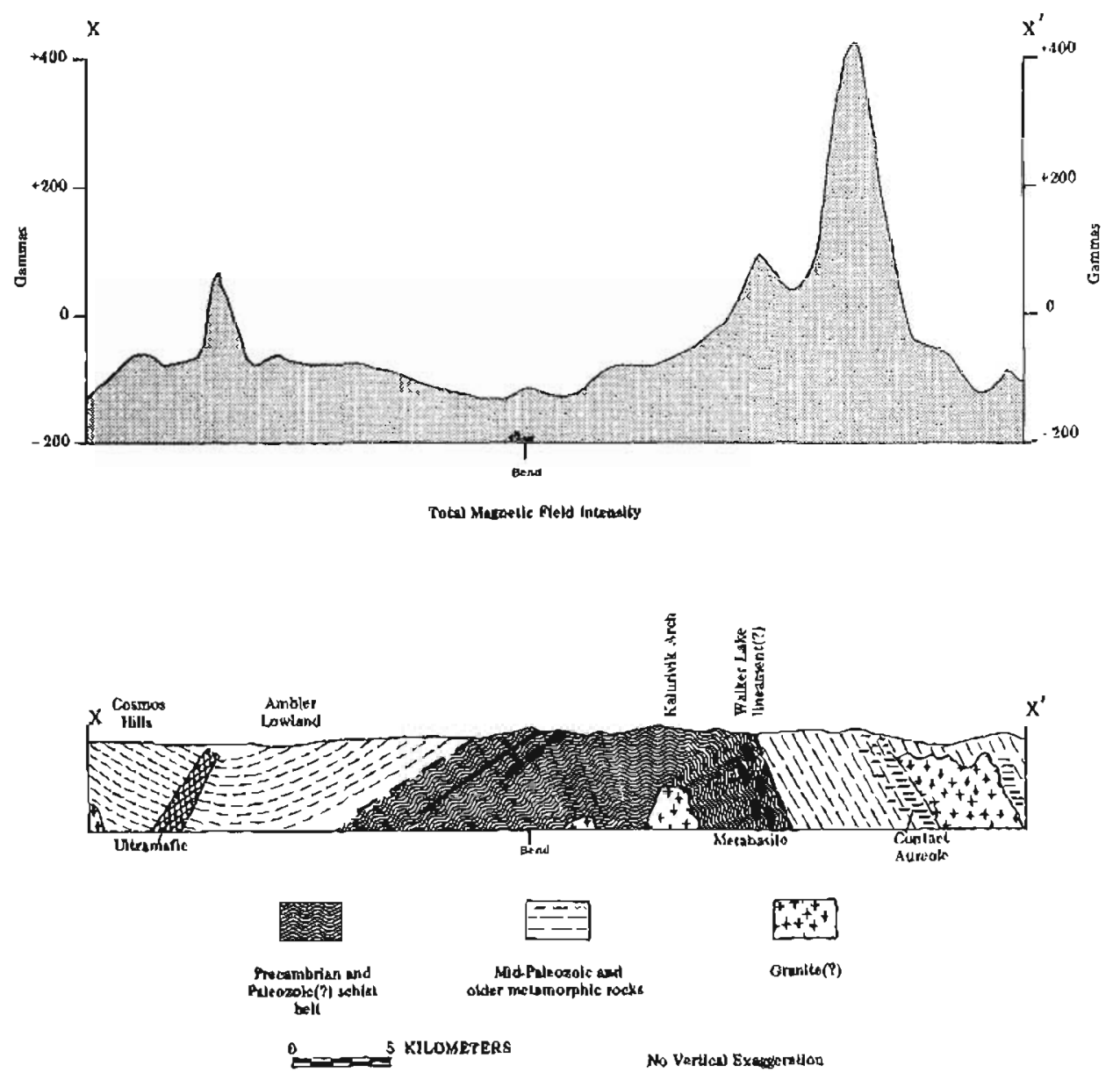

Figure 17. Schematic geologic cross section and aeromagnetic profile along $\mathrm{X} \cdot \mathrm{X}^{\prime}$ of $\mathrm{fig} .1$.

major change in magnetic gradient just described. Where the Walker Lake lineament has a sharply defined magnetic signature to the east, it appears to be a thrust fault. The broadening and curved nature of this signature near Ruby Ridge corresponds with the northverging overturned antilorm and synform on the north end of Ruby Ridge.

The Redstone and Shishakshinovick plutons are characterized by low-amplitude magnetic anomalies (fig. 16). Contact metamorphic effects have produced magnetic aureoles adjacent to and within the Palcozoic basement that outline the southern margins of the intrusions. Magnetic patterns and configurations indicate a north dip for the Shishakshinovick pluton and a south dip for the Redstone pluton.

\section{TECTONIC SUMMARY}

The geology of Ruby Ridge suggests that most of the rocks in the southern Brooks Range schist belt were once shallow-marine sedimentary and mafic volcanic rocks of Precambrian age. During late Precambrian time these rocks were metamorphosed in the biueschist facies and converted into continental basement. Wiltse and Gilbert believe that a felsic volcanic assemblage, which included marine pelite and carbonate, was de posited unconformably on Precambrian basement during mid-Paleozoic time (Wiltse and Gilbert, 1977) and may represent magmatism associated with Brooks Range mid-Paleozoic urogeny. All authors of this paper believe that some Phanerozoic rocks are probably now tectonically intercalated with Precambrian rocks.

During Jurassic-Cretaceous time the schist-belt base. ment probably impinged against the Paleozoic Cosmos Hils-Angayucham terrane. The thrust faulting, isoclinal folding, and regional greenschist-tacies metamorphism seen on Ruby Ridge are likely only a small part of widespread Cretaceous tectonism and plutonism that affected the western Brooks Range (Tailleur and Brosge, 1970; Tailleur, 1973; Newman and others, 1977) and may be the deep-seated manifestation of deformational events that moved overlying Paleozoic assemblages northward to form the major nappe structures in the central part of the western Brooks Range (fig. 17). 
During Late Cretaceous or Tertiary time the schist belt was again folded and pcrhaps uplifted along the trelld of the Kalurivik Arch. The bett probably forned a structural high from which almosl all overlying rocks have been tectonically stripped or removed by exosion.

Aeromagnetic evidence (lig. 16) suggests that the tectonic boundary between thic Cosmos Hills-Angayucham terrane and the schist belt was reactivated as a strike-slip system during Tertiary time, Right-lateral movement along this zone may have caused readjustment of older rocks along secondary fultits.

\section{ACKNOWLEDGMENTS}

The authors wish to thank I,L. T'ailleur, W.P. Brosge, C.F. Mayfietd, and G.H. Pessel for many stimulating discussions of southem Brooks Range geology. 'Taillcur, May field, and J.T. Dillon provided helpful reviews of the manuscript, and J.I'. Kline, M.W. Henning, and J.W. Buza assisted field parties during 1975. The authors also wish to thank the U.S. Gcological Survey, Bear Creek Mining Company and Sunshinc Minjng Company for their assistance alld conperation with this study.

This research was partly supported by National Scenic Foundation grant GA 43004. Carclen is also grateful for support from a Geological Society of America Penrose bequest granl and a Sigma Xi granl in aid of research.

\section{REFERENCES CITED}

Brosge, W.P., and Pessel, G.H., 197\%. Preliminivy re comnaissance geologic map of the Survey Pass quadrangle, Alaska: U.S. Geol. Survey Open-File Ropl. 77-27.

Forbes, R.B., Turner, D.L., Gilbert, W.G., and Carden, J.R.. 1974, Ruby Ridge traverse, southwestern Brooks Range: Alaska Div. Geol. and Geophys. Sur veys 1973 Ann. Rept., 1. 34-36.

Fritts, C.E., 1969, Geology and geochenistry in the southeastern part of the Cosmos Hills, Shungnate D-2 quadrangle, Alaska: Alaska Div. Mines and Geol. Geol. Rept. 37, 35 p., map.

1970, Geology and geochemistry of the Cosmos Hills, Ambler River and Shungnak quadyangles, Alaska: Alaska Div. Mincs and Geol. Geol. Rept. 39, 69 p., map.

1971, Geology and geochemistry of the Angayucham Mountains, western Alaska: Alaska Dív, of Geol. Survey 1970 Ann. Rept.. 1). 1.8, 1.9.

Fritts, C.E., Eakins, G.R., and Garland, R.E., 1972, Geology and geochemistry near Walker Lake, southern Survey Pass quadrangle, aretic Alaska: Alaska Div. Geol. Survey 1971 Anı. Rept., p. 19-26.
Mayfield, C.F., 1975, Metamorphism in southwestern Brooks Range: Geological Survey Research 1975, U.S. Geol. Survey Proí. Paper 975, p. 64-65.

Newrnan, G.W., Mull, C.G., and Watkins, N.D., 1977 , Nortbern Alaska paleomagnetism, plate rotation, and lectonics, in The relalionship of plate lectonics to Alaska geology and resources: Alaska Geal. Soc. Symposium, 1977, Anchorage, AK, p. 16-19.

Patton, W.W., Jr., Miller, T.P., and Tailleur, I.L., 1968, Regional geolngic map of the Shungnak and southern part of the Ambler River quadrangle, Alaska: U.S. Geol. Survey Misc. Geol. Inv. Map I-554.

Patton, W.W., Jr., and Miller, T.P., 1973, Bedrock seologic map of Bettles and southern part of Wiseman quadrangle, Alaska: U.S. Geol. Survey Mineral Inv. Map MF-402.

Pessel, G.It, Eakins, G.R., und Garland, R.E., 1973a, Geology and geochemistry of the southeastern Ambler River quadrangle, in Alaska Div. Geol. and Genphy. Surveys 1972 Ann. Rept., P. 7-8.

Pessel, G.H., Garland, R.E., Tailleur, I.L., and Eakins, G.R., $1973 \mathrm{~b}$, Preliminary geologic map of southeastern Ambler River and part of Survey Pass quadrangle, Alaska: Alaska Div. Gcol. and Geophys. Surveys Open-File Repl. 36.

Pessel, G.H., and Brosge, W.P., 1977, Preliminary reconnaissance freologic map of Ambler River quadrangle, Alaska: U.S. Geol. Survey Open-File Kept. 77-28.

Tailleur, I.I.., and Brosge, W.P., 1970, Tectonic history of northem Alaska, in Proceedings of the geological seminar on the north slope of Alaska: Los Angeles, Pacilic Sec., Am. Assoc. Petroleum Geologists, p. E1E19.

Tailleur, I.J.., 1973, Probable rift origin of the Canada Basin. Arelic Ocem, in Arctic genlogy (M.G. Pitcher, nd.): Am. Assoc. Petraleum Gcologists Mem. 19, 1). $526-535$.

Taylor, H.P., and Coleman, R.G., 1968, $\mathrm{O}^{18} / \mathrm{O}^{16}$ ratios of co-existing minerals in glaucophane-bearing melamorphic rocks: Geol. Soc. America Bull, v. 79, p. 1727-1766.

Turner, D.L., 1974, Geochronology of southwestern Brooks Range melamorphic rocks: Alaska Div. Geol. and Geophys, Surveys 1973 Ann. Rept., p. 27-30.

Turner, D.L., and Forbes, R.B., 1977, Geochronology of the southwestern Brooks Range, in The relationship of plate lectonics to Alaskan geology and re. sources: Alaska Geol. Soc. Symposium, 1977, Anchorage, AK, p, 42-43.

Wiltse, M.A., 1975, Geology of the Arctic Camp prospect, Ambler Kiver quadrangle, Alastea: Alaska Div. Geol. and Geophys. Surveys Open-File Rept. G0.

Wiltse, M.A., and Gilbert, W.G., 1977, Regional setting of southern Brooks Range copper deposits, Alaska: Geol. Assoc, Canada Annual Mecting, 1977, Vancolver, B.C., Prog. with A.bs., v. 2, p. 55. 
dominant foliation $\left(\mathrm{S}_{1}\right)$; it rarely occurs as bodies up to several meters thick that cut across the dominant foliation. Exposures range from massive, jointed, angular outcrops surrounded by large, blocky boulders to wellfoliated, schistose-slabby outcrops. The metabasite interval on the crest. of Ruby Ridge $1.7 \mathrm{~km}$ north of VABM 3870 has pillow structures. The parent material of the metabasite probably consisted of basalt flows and gabbroic intrusions (table 1).

There is a continuous variation between massive. coarse-grained, glaucophane-bearing metabasite and oc. casionally foliated, fine- to medium-grained greenstone with greenschist-facies mineral assemblages (figs. 3, 4, and 5), but the two end members will be described separately.

\section{GLAUCOPHANE-BEARING METABASITE}

These rocks are generally massive with no apparent. schistosity and form prominent ridges (fig. 2). Fresh samples are blue to bluish green, with a coarse-grained, poikioblastic granular texture highlighted by reddish. brown garnets that stand out in relief on weathered surfaces. The absence of schistosity, which is unusual for glaucophane schist, appears to be due to the lack of penetrative deformation. However, a crude foliation was observed in a few partially retrograded rocks and appears to be defined by minerals such as chlorite. actinolite, and white mica that crystallized during the later greenschist-facies event. A notable exception is a metabasite near the axis of the Kalurivik Arch that has a well-defined schistosity defined by the parallel align. ment of subidioblastic glaucophane prisms.

The main metamorphic minerals present in glauco. phane-bearing metabasite are garnet, glaucophane, epi. dote, sphene, rutile, chlorite, and white mica. This

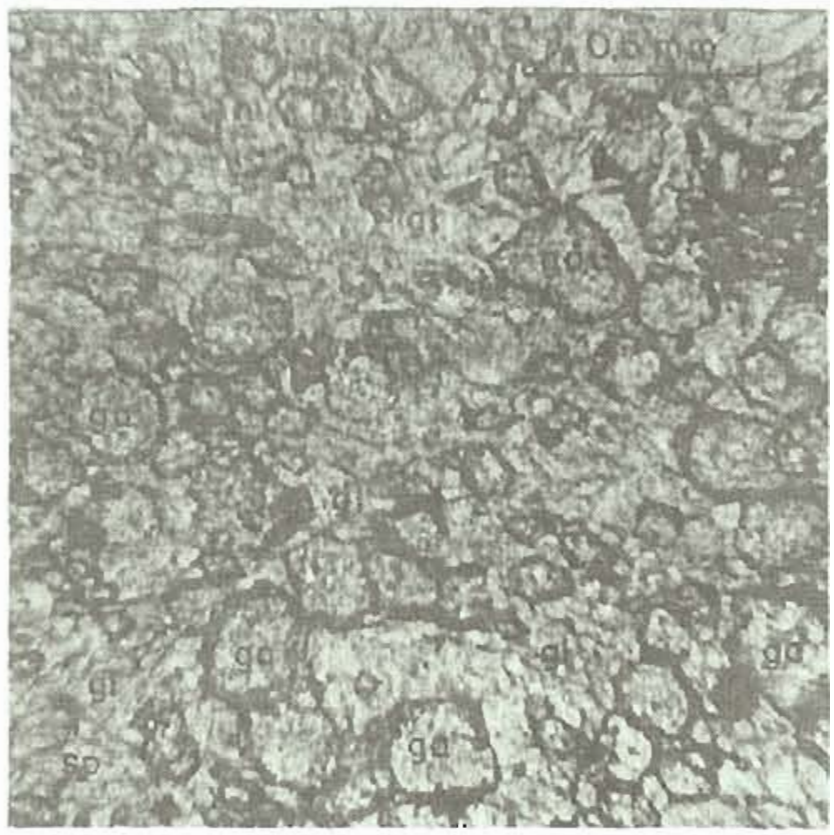

Figure 3. Photomicrograph of garnet-glaucophane metabasite. ga - garnet, gl - glaucophane, sp - sphene.

mineral assemblage is evidence that the earliest metamorphism to affect the schist belt was of the blueschist facies.

Garnet, which makes up from 10 to 60 percent of these rocks, occurs as pinkish-brown porphyroblasts ranging from 0.1 to $1.5 \mathrm{~mm}$ in diameter (fig. 3, cover photograph) and commonly exhibits irregular, chloritefilled fractures. Garnet exhibits all degrees of retrograde metamorphism, from thin chlorite jackets to small islands of garnet that have been completely en-

Table 1. Chemical analyses (in weight-percent) of metaigneous rocks on Ruby Ridge (USGS rapid-rock analyses).

\begin{tabular}{|c|c|c|c|c|c|}
\hline & \multicolumn{2}{|c|}{ Metafelsite } & \multicolumn{3}{|c|}{ Metabasite } \\
\hline & $\begin{array}{c}\text { Sample } \\
\text { 73RR19f } \\
\text { (Locality 1) }\end{array}$ & $\begin{array}{c}\text { Sample } \\
\text { 73RR20-3 } \\
\text { (Locality 2) }\end{array}$ & $\begin{array}{c}\text { Sample } \\
\text { 73RR63f } \\
\text { (Locality 3) }\end{array}$ & $\begin{array}{c}\text { Sample } \\
\text { 73RR1c } 1 \\
\text { (Locality 4) }\end{array}$ & $\begin{array}{c}\text { Sample } \\
73 \text { R } 52 \text { ). } \\
\text { (Locality } 5 \text { ) }\end{array}$ \\
\hline $\mathrm{SiO}_{2}$ & 70.3 & 72.1 & 47.4 & 50.7 & 49.6 \\
\hline $\mathrm{Al}_{2} \mathrm{O}_{3}$ & 13.5 & 14.0 & 16.0 & 13.2 & 13.5 \\
\hline $\mathrm{Fe}_{2} \mathrm{O}_{3}$ & 1.4 & 0.68 & 1.9 & 4.5 & 3.3 \\
\hline $\mathrm{FeO}$ & 2.4 & 0.84 & 9.4 & 9.4 & 12.2 \\
\hline $\mathrm{MgO}$ & 2.5 & 0.67 & 7.1 & 6.1 & 5.5 \\
\hline $\mathrm{CaO}$ & 0.23 & 0.51 & 8.1 & 9.6 & 6.7 \\
\hline $\mathrm{Na}_{2} \mathrm{O}$ & 1.2 & 1.1 & 3.3 & 3.3 & 2.5 \\
\hline $\mathrm{K}_{2} \mathrm{O}$ & 5.9 & 7.0 & 0.12 & 0.52 & 0.06 \\
\hline $\mathrm{H}_{2}^{2} \mathrm{O}+$ & 1.6 & 0.97 & 3.2 & 0.93 & 1.7 \\
\hline $\mathrm{H}_{2}^{2} \mathrm{O}$. & 0.11 & 0.09 & 0.18 & 0.00 & 0.09 \\
\hline $\mathrm{TiO}_{2}$ & 0.52 & 0.42 & 1.7 & 1.6 & 3.7 \\
\hline $\mathrm{P}_{2} \mathrm{O}_{5}^{2}$ & 0.15 & 0.09 & 0.23 & 0.15 & 0.39 \\
\hline $\mathrm{MnO}$ & 0.02 & 0.00 & 0.14 & 0.17 & 0.21 \\
\hline $\mathrm{CO}_{2}$ & 0.02 & 0.08 & 1.0 & 0.33 & 0.56 \\
\hline
\end{tabular}

${ }^{1}$ Contains glaucophane. 


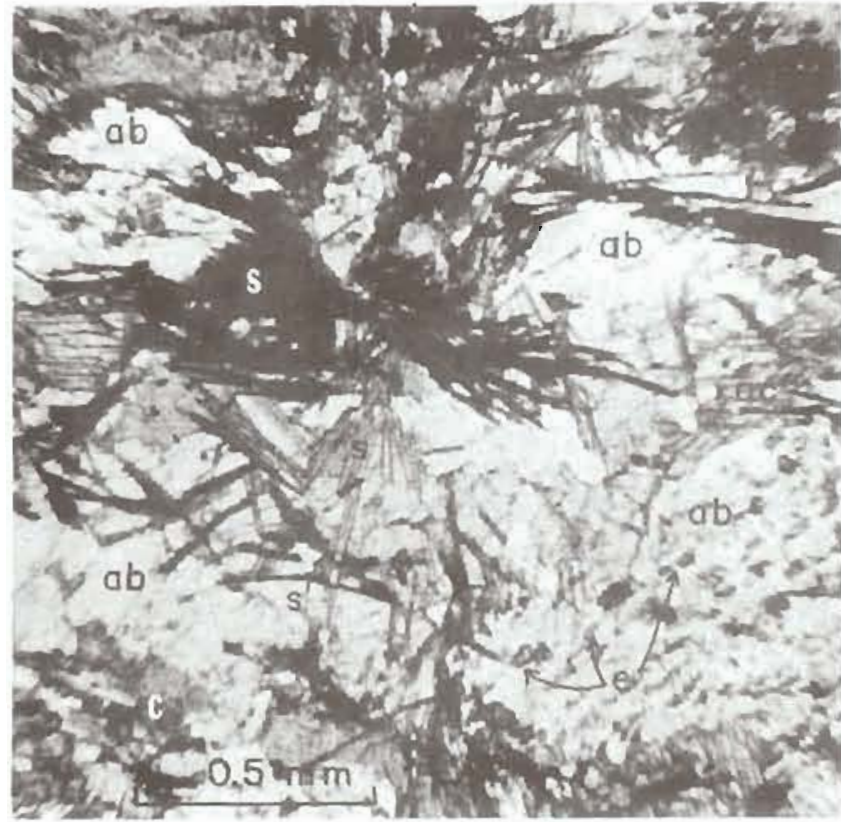

Figure 5. Photomicrograph of greenschist metabasite. ab - albite, s - stilpnomelane, c - chlorite, e - epidote.

blasts, or as a felty aggregate that accounts for 20 to 60 percent of the rock.

Epidote or clinozoisite typically: occurs as idioblastic to subidioblastic prisms $0.1-1.0 \mathrm{~mm}$ long elongated along their $b$ axis and parallel to the plane of foliation. As in glaucophane-bearing metabasite, epidote is generally zoned from iron-rich cores to iron-poor rims. The zoning is thought to be due to the increase in crystallization temperature associated with greenschistfacies metamorphism that affected earlier formed epidote.

Two generations of garnet are recognized in these rocks: (1) that formed during the blueschist facies metamorphic event, which is retrograded and occurs as small xenoblasts surrounded by chlorite (fig. 6), and (2) that formed during the subsequent greenschistfacies event, which occurs as idioblastic porphyroblasts and is not altered to chlorite.

Albite is present as helicitic untwinned xenoblasts up to $1.5 \mathrm{~mm}$ in diameter. Weakly pelochroic chlorite occurs as interstitial laths and aggregates located between larger amphibole, clinozoisite, and garnet grains.

Minor minerals commonly present in these rocks are sphene, quartz, calcite, stilpnomelane (fig. 5) and biotite. Sphene is the most common nonopaque accessory mineral and occurs as euhedral grains, in trains, or as aggregates. Quartz occurs as early-formed, clear, equant, or lenticular grains, whereas sphene and calcite formed late in the paragenesis of these rocks. Rare stilpnomelane occurs as radiating aggregates associated with calcite on the south part of Ruby Ridge, and incipient biotite is seen forming from chlorite in a few samples from the north end of the ridge.
In most cases, greenschist-facies metabasite was previously metamorphosed to high-temperature blue. schist facies, although it is difficult to distinguish rocks that are retrograded blueschists from greenschist-facies metabasite formed directly from gabbro or basalt. In many specimens, however, there is excellent textural and mineralogical evidence for formation of greenschists from blueschists (fig. 4). The absence of biotite in blueschist-facies rocks is diagnostic, as previously noted by Taylor and Coleman (1968). However, on the north end of Ruby Ridge, where greenschist-facies metamorphism was most intense, biotite appears as a stable phase in synkinematic assemblages.

The first minerals to be attacked by the retrograde metamorphism are glaucophane and garnet. Glaucophane is usually replaced by a pale-green amphibole that mimics original glaucophane textures (fig. 4). Garnet alters to chlorite, which forms pseudomorphic aggregates after the original porphyroblasts (fig. 6). Epidote in some of the blueschist assemblages has undergone a more subtle transition. South of VABM Ruby epidote grains are commonly zoned from iron-rich cores to iron-poor rims (clinozoisite in many instances). North of peak 3870 clinozoisite is the stable epidote mineral and is usually found as large porphyroblasts. Epidote rarely occurs as inclusions in garnet or albite.

\section{METAFELSITE}

Two east-trending bands of felsic schist are present just north and northeast of VABM Ruby (pl. 1). The occurrences are separated by intervening pelitic schist, metabasite, and a thrust fault. The northern felsic schist was probably once laterally continuous with the south. ern sequence. Most felsic schist is light gray on both fresh and weathered surfaces and forms low angular ridges to subdued and rounded outcrops mantled with slabby talus. A distinctive feature of some outcrops is the presence of slightly elongate, curved slabs and prisms of rock that resemble the sinuous columnarjointing characteristics of small felsic volcanic domes. The felsic schist commonly contains quartz \pm microcline + muscovite-phengite \pm biotite + albite \pm talc $(?) \pm$ chlorite + clinozoisite-epidote + sphene + apatite + zircon + calcite. Biotite or microcline or both are characteristic of this schist. When present, microcline appears to be recrystallized premetamorphic K-feldspar phenocrysts. The microcline crystals are often euhedral or are angular fragments of euhedral crystals, and deep sinuous embayments randomly penetrate the megacrysts. Some specimens show foliation bending around microcline, while in a few cases foliation seems little altered by the presence of megacrysts $1.5-2.0 \mathrm{~cm}$ across. Some intervals are markedly blastoporphyritic with megacrysts of partially resorbed bluish quartz as well as K-feldspar. Except for anhedral form and smaller size, quartz megacrysts closely resemble microcline megacrysts. The quartz and microcline megacryst; 